\title{
Inputs and processes affecting the distribution of particulate iron in the North Atlantic along the GEOVIDE (GEOTRACES GA01) section
}

\author{
Arthur Gourain $^{1, \mathrm{a}}$, Hélène Planquette ${ }^{1}$, Marie Cheize ${ }^{1, \mathrm{~b}}$, Nolwenn Lemaitre ${ }^{1, \mathrm{c}}$, Jan-Lukas Menzel Barraqueta ${ }^{2, \mathrm{~d}}$, \\ Rachel Shelley $^{1, \mathrm{e}}$, Pascale Lherminier ${ }^{3}$, and Géraldine Sarthou ${ }^{1}$ \\ ${ }^{1}$ UMR 6539/LEMAR/IUEM, CNRS, UBO, IRD, Ifremer, Technopôle Brest Iroise, \\ Place Nicolas Copernic, 29280 Plouzané, France \\ ${ }^{2}$ GEOMAR, Helmholtz Centre for Ocean Research Kiel, Wischhofstraße 1-3, 24148 Kiel, Germany \\ ${ }^{3}$ Ifremer, Univ. Brest, CNRS, IRD, Laboratoire d'Océanographie Physique et Spatiale (LOPS), \\ IUEM, 29280 Plouzané, France \\ ${ }^{a}$ now at: Ocean Sciences Department, School of Environmental Sciences, University of Liverpool, Liverpool, L69 3GP, UK \\ ${ }^{b}$ now at: Ifremer, Centre de Brest, Géosciences Marines, Laboratoire des Cycles \\ Géochimiques (LCG), 29280 Plouzané, France \\ ${ }^{c}$ now at: Department of Earth Sciences, Institute of Geochemistry and Petrology, ETH-Zürich, Zürich, Switzerland \\ dnow at: Department of Earth Sciences, Stellenbosch University, Stellenbosch, 7600, South Africa \\ enow at: Earth, Ocean and Atmospheric Science, Florida State University, Tallahassee, Florida 32310, USA
}

Correspondence: Hélène Planquette (helene.planquette@univ-brest.fr)

Received: 17 May 2018 - Discussion started: 28 May 2018

Revised: 25 March 2019 - Accepted: 31 March 2019 - Published: 12 April 2019

\begin{abstract}
The aim of the GEOVIDE cruise (May-June 2014, R/V Pourquoi Pas?) was to provide a better understanding of trace metal biogeochemical cycles in the North Atlantic Ocean. As marine particles play a key role in the global biogeochemical cycle of trace elements in the ocean, we discuss the distribution of particulate iron $(\mathrm{PFe})$, in relation to the distribution of particulate aluminium (PAl), manganese (PMn), and phosphorus (PP). Overall, 32 full vertical profiles were collected for trace metal analyses, representing more than 500 samples. This resolution provides a solid basis for assessing concentration distributions, elemental ratios, size fractionation, and adsorptive scavenging processes in key areas of the thermohaline overturning circulation. Total particulate iron concentrations ranged from as low as $9 \mathrm{pmol} \mathrm{L}^{-1}$ in surface waters of the Labrador Sea to $304 \mathrm{nmol} \mathrm{L}^{-1}$ near the Iberian margin, while median PFe concentrations of $1.15 \mathrm{nmol} \mathrm{L}^{-1}$ were measured over the sub-euphotic ocean interior.

Within the Iberian Abyssal Plain, the ratio of $\mathrm{PFe}$ to PAl was identical to the continental crust molar ratio $\left(0.21 \mathrm{~mol} \mathrm{~mol}^{-1}\right)$, indicating the important influence of
\end{abstract}

crustal particles in the water column. Overall, the lithogenic component explained more than $87 \%$ of PFe variance along the section. Within the Irminger and Labrador basins, the formation of biogenic particles led to an increase in the PFe/PAl ratio (up to $0.64 \mathrm{~mol} \mathrm{~mol}^{-1}$ ) compared to the continental crust ratio. Continental margins induce high concentrations of particulate trace elements within the surrounding water masses (up to $10 \mathrm{nmol} \mathrm{L}^{-1}$ of PFe). For example, horizontal advection of $\mathrm{PFe}$ was visible more than $250 \mathrm{~km}$ away from the Iberian margin. Additionally, several benthic nepheloid layers were observed more than $200 \mathrm{~m}$ above the seafloor along the transect, especially in the Icelandic, Irminger, and Labrador basins, suspending particles with high PFe content of up to $89 \mathrm{nmol} \mathrm{L}^{-1}$. 


\section{Introduction}

Particles play a key role in the ocean, where they drive the residence time of most elements (Jeandel and Oelkers, 2015) and strongly influence the global biogeochemistry of macroand micro-nutrients including iron (Milne et al., 2017). In the surface ocean, biological activity produces biogenic suspended matter through planktonic organisms, while atmospheric deposition (Jickells et al., 2005; Baker et al., 2013), riverine discharge (Ussher et al., 2004; Berger et al., 2008; Aguilar-Islas et al., 2013), or ice melting (Lannuzel et al., 2011, 2014; Hawkings et al., 2014) deliver mostly lithogenicderived particles to surface waters. These particulate inputs are highly variable, both spatially and seasonally, in the world's oceans. At depth, benthic and shelf sediment resuspension (e.g. Fitzwater et al., 2000; McCave and Hall, 2002; Elrod et al., 2004; Lam and Bishop, 2008; Cullen et al., 2009; Hwang et al., 2010; Aguilar-Islas et al., 2013; Lam et al., 2015) and hydrothermal activity (Trefry et al., 1985; Elderfield and Schultz, 1996; Tagliabue et al., 2010, 2017; Lam et al., 2012) provide important amounts of particles to the water column. Moreover, authigenic particles can be produced in situ by aggregation of colloids (Bergquist et al., 2007) or oxidation processes (Bishop and Fleisher, 1987; Collier and Edmond, 1984). Thus, oceanic particles result from a complex combination of these different sources and processes (Lam et al., 2015).

In the upper water column, the total iron pool is dominated by marine particles (Radic et al., 2011) which strongly interact with the dissolved pool (e.g. Ellwood et al., 2014). Indeed, dissolved iron can be scavenged onto particles (Rijkenberg et al., 2014; Gerringa et al., 2015), incorporated into biogenic particles (Berger et al., 2008), or produced by remineralization of particles (Dehairs et al., 2008; Sarthou et al., 2008). Interestingly, the concept of "reversible scavenging" of iron (i.e. release at depth of dissolved iron previously scavenged onto particles) has been advocated recently (Labatut et al., 2014; Dutay et al., 2015; Jeandel and Oelkers, 2015; Abadie et al., 2017), while other studies reveal distinct dissolution processes of inorganic particulate iron (e.g. Oelkers et al., 2012; Cheize et al., 2018). Slow dissolution of particulate iron at margins has also been evoked as a continuous fertilizer of primary production and should be considered as a source of dissolved iron (e.g. Lam and Bishop, 2008; Jeandel et al., 2011; Jeandel and Oelkers, 2015). Within or below the mixed layer, the rates of regeneration processes can also impact the bioavailable pool of iron, among other trace metals (e.g. Ellwood et al., 2014; Nuester et al., 2014). However, the rates of these processes are not yet fully constrained. The study of particulate iron is thus essential to better constrain its marine biogeochemical cycle. Interest has grown in this subject over the last 10 years, in particular (e.g. Bishop and Biscaye, 1982; Collier and Edmond, 1984; Sherrell et al., 1998; Frew et al., 2006; Planquette et al., 2011, 2013; Lam et al., 2012; Abadie et al., 2017; Milne et al., 2017), and, to our knowledge, only two studies have been performed on an ocean-wide scale: the GA03 GEOTRACES North Atlantic Zonal Transect (Lam et al., 2015; Ohnemus and Lam, 2015) and the GP16 GEOTRACES Pacific Transect (Lam et al., 2017; Lee et al., 2017).

Within this global context, this paper presents the particulate iron distribution of the North Atlantic Ocean, along the GEOTRACES GA01 section (GEOVIDE), and discusses the various sources and processes affecting particulate iron ( $\mathrm{PFe})$ distribution, using particulate aluminium (PAl), phosphorus (PP), or manganese (PMn) distributions to support our conclusions.

\section{Methods}

\subsection{Study area}

Particulate samples were collected at 32 stations during the GEOVIDE (GEOTRACES GA01 section) cruise between May and June 2014 aboard the R/V Pourquoi Pas? in the North Atlantic Ocean (Sarthou et al., 2018). The sampling spanned several biogeochemical provinces (Fig. 1), starting over the Iberian margin (IM, stations 2, 4, and 1), and proceeding to the Iberian Abyssal Plain (IAP, stations 11 to 17), the Western European Basin (WEB, station 19 to station 29), and the Icelandic Basin (IcB, stations 32 to 36). Then, samples were collected above the Reykjanes Ridge (RR, station 38), in the Irminger Basin (IrB, stations 40 to 60), close to the Greenland Shelf (GS, stations 53, 56, and 61), the Labrador Basin (LB, stations 63 to 77), and finally close the Newfoundland Shelf (NS, station 78) (Fig. 1). The North Atlantic is characterized by a complex circulation (briefly described in Sect. 3.1 and in detail by Zunino et al., 2017, and García-Ibáñez et al., 2015) and is one of the most productive regions of the global ocean (Martin et al., 1993; Sanders et al., 2014).

\subsection{Sampling}

Samples were collected using the French GEOTRACES clean rosette, equipped with $2212 \mathrm{~L}$ GO-FLO bottles (2 bottles were leaking and were not deployed during the cruise). GO-FLO bottles (General Oceanic's) were initially cleaned in the home laboratory (LEMAR) following the GEOTRACES procedures (Cutter and Bruland, 2012). The rosette was deployed on a $14 \mathrm{~mm}$ Kevlar cable with a dedicated, custom-designed clean winch. Immediately after recovery, the GO-FLO bottles were individually covered at each end with plastic bags to minimize contamination. Bottles were then transferred into a clean container (class-100) for sampling. On each cast, nutrient and/or salinity samples were taken to check potential leakage of the GO-FLO bottles.

Filters were cleaned following the GEOTRACES protocols (http://www.geotraces.org/images/Cookbook.pdf, last access: 9 April 2019) and kept in acid-cleaned 1L LDPE 


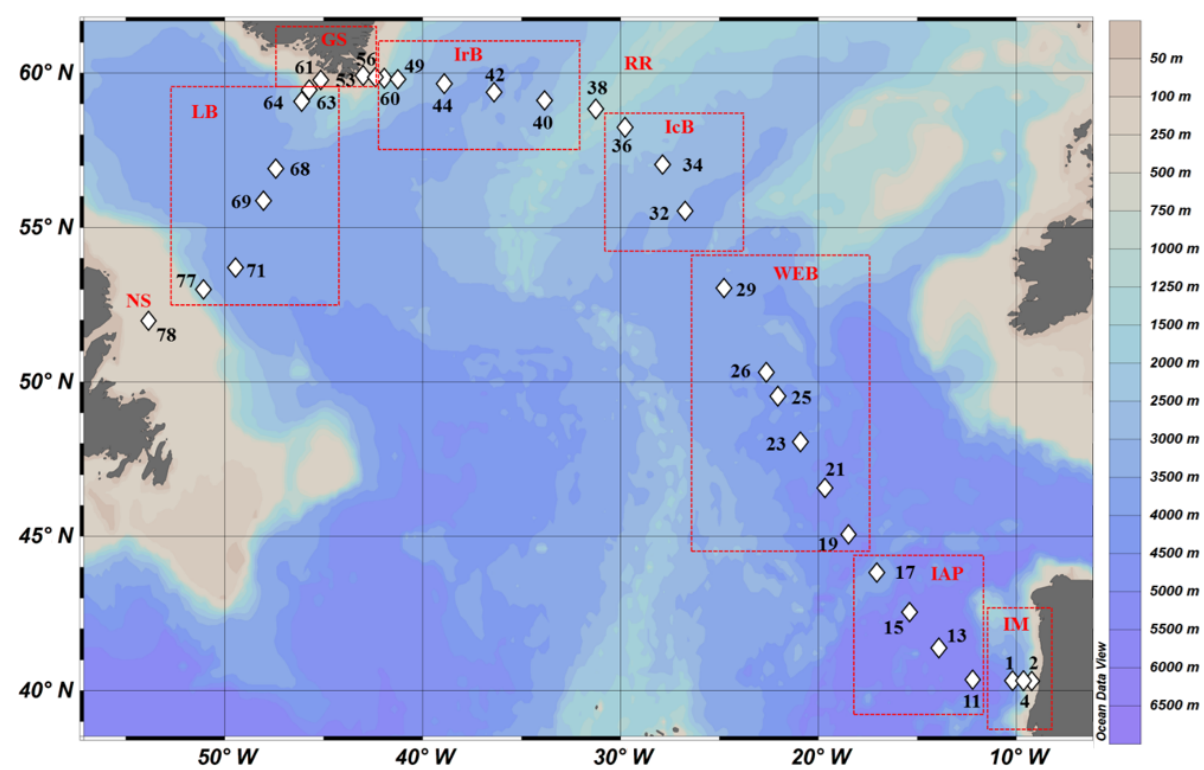

Figure 1. Map of stations where suspended particle samples were collected with GO-FLO bottles during the GEOVIDE cruise (GA01) in the North Atlantic Ocean. Biogeochemical provinces are indicated by red squares; IM: Iberian margin, IAP: Iberian Abyssal Plain, WEB: Western European Basin, IcB: Iceland Basin, RR: Reykjanes Ridge, IrB: Irminger Basin, GS: Greenland Shelf, LB: Labrador Basin, NS: Newfoundland Shelf. This figure was generated using Ocean Data View (Schlitzer, R., Ocean Data View, 2017, http://odv.awi.de/, last access: 9 April 2019).

bottles (Nalgene) filled with ultrapure water (Milli-Q, resistivity of $18.2 \mathrm{M} \Omega \mathrm{cm}$ ) until use. All filters were $25 \mathrm{~mm}$ in diameter in order to optimize the signal over the filter blank, except at the surface depth where $47 \mathrm{~mm}$ diameter filters were used. The filters were mounted on acid-cleaned polysulfone filter holders $\left(\mathrm{Nalgene}^{\mathrm{TM}}\right)$. Prior to filtration, the GO-FLO bottles were shaken three times, as recommended in the GEOTRACES cookbook to avoid settling of particles in the lower part of the bottle. GO-FLO bottles were pressurized to $<8$ psi with $0.2 \mu \mathrm{m}$ filtered nitrogen gas $\left(\mathrm{N}_{2}\right.$, Air Liquide). Seawater was then filtered directly through paired filters (Pall Gelman Supor ${ }^{\mathrm{TM}} 0.45 \mu \mathrm{m}$ polyetersulfone, and Millipore mixed ester cellulose MF $5 \mu \mathrm{m}$ ) mounted in Swinnex polypropylene filter holders (Millipore), following Planquette and Sherrell (2012), inside the clean container. Filtration was operated until the bottle was empty or until the filter clogged; the volume filtered ranged from $2 \mathrm{~L}$ for surface samples to $11 \mathrm{~L}$ within the water column. After filtration, filter holders were disconnected from the GO-FLO bottles and a gentle vacuum was applied using a syringe in order to remove any residual water under a laminar flow hood. Filters were then removed from the filter holders with plastic tweezers (which were rinsed with Milli-Q between samples). Most of the remaining seawater was removed via "sipping" by capillary action, when placing the non-sampled side of the filter onto a clean $47 \mathrm{~mm}$ Supor $^{\mathrm{TM}}$ filter. Each filter pair was then placed in an acid-cleaned polystyrene PetriSlide (Millipore), double bagged, and finally stored at $-20^{\circ} \mathrm{C}$ until analysis at LEMAR. Between casts, filter holders were thoroughly rinsed with Milli-Q, placed in an acid bath (5\% Trace metal grade $\mathrm{HCl}$ ) for $24 \mathrm{~h}$, and then rinsed with Milli-Q.

At each station, process blanks were collected as follows: $2 \mathrm{~L}$ of a deep $(1000 \mathrm{~m})$ and a shallow $(40 \mathrm{~m})$ seawater sample was first filtered through a $0.2 \mu \mathrm{m}$ pore size capsule filter (Pall Gelman Acropak 200) mounted on to the outlet of the GO-FLO bottle before passing through the particle sampling filter, which was attached directly to the Swinnex filter holder.

\subsection{Analytical methods}

In the home laboratory, sample handling was performed inside a clean room (Class 100). All solutions were prepared using ultrapure water (Milli-Q) and all plastic ware had been acid-cleaned before use. Frozen filters, collected within the mixed layer or within nepheloid layers, were first cut in half using a ceramic blade: one filter half was dedicated to total digestion (see below), while the other half was archived at $-20^{\circ} \mathrm{C}$ for SEM analyses or acid leaching of "labile" metals following the Berger et al. (2008) method (to be published separately).

Filters were digested following the method described in Planquette and Sherrell (2012). Filters were placed on the inner wall of acid-cleaned $15 \mathrm{~mL}$ PFA vials $\left(\right.$ Savillex $^{\mathrm{TM}}$ ), and $2 \mathrm{~mL}$ of a solution containing $2.9 \mathrm{~mol} \mathrm{~L}^{-1}$ hydrofluoric acid (HF, suprapur grade, Merck) and $8 \mathrm{~mol} \mathrm{~L}^{-1}$ nitric acid $\left(\mathrm{HNO}_{3}\right.$, Ultrapur grade, Merck) was added to each vial. Vials were then closed and refluxed at $130^{\circ} \mathrm{C}$ on a 
hot plate for $4 \mathrm{~h}$, after which the filters were removed. After cooling, the digest solution was evaporated at $110^{\circ} \mathrm{C}$ to near dryness. Then, $400 \mu \mathrm{L}$ of concentrated $\mathrm{HNO}_{3}$ (Ultrapur grade, Merck) was added, and the solution was re-evaporated at $110^{\circ} \mathrm{C}$. Finally, the obtained residue was dissolved with $3 \mathrm{~mL}$ of $0.8 \mathrm{~mol} \mathrm{~L}^{-1} \mathrm{HNO}_{3}$ (Ultrapure grade, Merck). This archived solution was transferred to an acid-cleaned $15 \mathrm{~mL}$ polypropylene centrifuge tube $\left(\mathrm{Corning}^{\circledR}\right)$ and stored at $4{ }^{\circ} \mathrm{C}$ until analyses.

All analyses were performed on a sector field inductively coupled plasma mass spectrometer (SF-ICP-MS Element 2, Thermo-Fisher Scientific). Samples were diluted by a factor of 7 on the day of analysis in acid-washed $13 \mathrm{~mm}$ (outer diameter) rounded bottom, polypropylene centrifuge tubes (VWR) with $0.8 \mathrm{~mol} \mathrm{~L}^{-1} \mathrm{HNO}_{3}$ (Ultrapur grade, Merck) spiked with $1 \mu \mathrm{g} \mathrm{L}-1$ of indium $\left({ }^{115} \mathrm{In}\right)$ solution in order to monitor the instrument drift. Samples were introduced with a PFA-ST nebulizer connected to a quartz cyclonic spray chamber (Elemental Scientific Incorporated, Omaha, NE) via a modified SC-Fast introduction system consisting of an SC-2 autosampler, a six-port valve, and a vacuum-rinsing pump. The autosampler was contained under a HEPA-filtered unit (Elemental Scientific). Two six-point, matrix-matched multi-element standard curves with concentrations bracketing the range of the samples were run at the beginning, the middle, and the end of each analytical run. Analytical replicates were made every 10 samples, while accuracy was determined by performing digestions of certified reference material BCR-414 (plankton, Community Bureau of Reference, Commission of the European Communities), PACS-3, and MESS-4 (marine sediments, National Research Council Canada), following the same protocol used for the samples. Recoveries were typically within $10 \%$ of the certified values (and within the error of the data, taken from replicate measurements, Table 1). Once all data were normalized to an ${ }^{115}$ In internal standard and quantified using an external standard curve, the dilution factor of the total digestion was accounted for. The elemental concentrations were obtained per filter (pmol/filter) and were then process blank-corrected. Finally, pmol/filter values were divided by the volume of water filtered through stacked filters.

Total concentrations (sum of small size fraction $(0.45-$ $5 \mu \mathrm{m})$ and large $(>5 \mu \mathrm{m})$ size fraction) of particulate trace elements are reported in Table S1 in the Supplement.

\subsection{Positive matrix factorization}

Positive matrix factorization (PMF) was run to characterize the main factors influencing the particulate trace element variance along the GEOVIDE section. In addition to PFe, $\mathrm{PAl}, \mathrm{PMn}$, and PP, nine additional elements were included in the PMF: yttrium (Y), barium (Ba), lead $(\mathrm{Pb})$, thorium $(\mathrm{Th})$, titanium $(\mathrm{Ti})$, vanadium $(\mathrm{V})$, cobalt $(\mathrm{Co})$, copper $(\mathrm{Cu})$, and zinc ( $\mathrm{Zn})$. The PMF was conducted on samples where all elements were above their detection limits; after selection, 445 of the 549 existing data points were used. Analyses were performed using the PMF software, EPA PMF 5.0, developed by the USA Environmental Protection Agency (EPA). Three- to six-factor models were run on the data. The configuration that provided the lowest error estimation (i.e. was the most reliable) was the four-factor model. To ensure stability, this model was run 100 times. After displacement, error estimation, and bootstrap error estimation, the model was recognized as stable.

\subsection{Derived and ancillary parameters}

To investigate the proportion of lithogenic iron within the bulk particulate iron, we used the upper continental crust (UCC) Fe/Al molar ratio (0.21) of Taylor and McLennan (1995) to calculate the lithogenic components of particles $\left(\% \mathrm{PFe}_{\text {litho }}\right)$ following Eq. (1):

$\% \mathrm{PFe}_{\text {litho }}=100 \times\left(\frac{\mathrm{PAl}}{\mathrm{PFe}}\right)$ sample $\times\left(\frac{\mathrm{PFe}}{\mathrm{PAl}}\right)$ UCCratio

The non-lithogenic PFe is obtained using Eq. (2):

$\% \mathrm{PFe}_{\text {non-litho }}=100-\% \mathrm{PFe}_{\text {litho }}$

Note that while the $\% \mathrm{PFe}_{\text {litho }}$ and $\% \mathrm{PFe}_{\text {non-litho }}$ proxies are interesting tools to evaluate the importance of lithogenic and non-lithogenic (either biogenic or authigenic) fractions, they have to be used carefully, as the spatial and temporal variation of the lithogenic component ratios may involve uncertainties of the estimated fraction value.

In addition to PAl, PMn can be used as a tracer of inputs from shelf resuspension (Lam and Bishop, 2008), using a percentage of sedimentary inputs "\%bulk sediment inputs" estimated according to the following equation:

$$
\begin{aligned}
\text { \%bulk sediment PMn }= & 100 \times\left(\frac{\mathrm{PAl}}{\mathrm{PMn}}\right) \text { sample } \\
& \times\left(\frac{\mathrm{PMn}}{\mathrm{PAl}}\right) \text { UCCratio, }
\end{aligned}
$$

with PAl/PMn being the ratio from the GEOVIDE samples and the PMn/PAl being the UCC value (0.0034; Taylor and McLennan, 1995).

This proxy can be a good indicator of sediment resuspension. We assume that particles newly resuspended in the water column will have the same PMn/PAl ratio as the UCC ratio, leading to a "\%bulk sediment Mn" of $100 \%$. This proxy assumes homogeneity of the sediment PMn/PAl ratio throughout the GEOVIDE section. However, this may not be the case at every station. In consequence, this proxy should only be used to identify new benthic resuspension at specific locations; inter-comparison between several locations may not be appropriate. When a sample presents a "\%bulk sediment Mn" greater than $100 \%$, we have assigned a maximum value of $100 \%$. As the Mn cycle can also be influenced 
Table 1. Blank and limit of detection $\left(\mathrm{nmol} \mathrm{L}^{-1}\right)$ of the two filters and certified reference material (CRM) recoveries during GEOVIDE suspended particle digestions.

\begin{tabular}{ll|rrrr}
\hline & & Fe & Al & P & Mn \\
\hline Blank $\left(\mathrm{nmol} \mathrm{L}^{-1}\right)$ & $5 \mu \mathrm{m}$ filter & 0.072 & 0.100 & 0.511 & 0.003 \\
& $0.45 \mu \mathrm{m}$ filter & 0.132 & 0.164 & 1.454 & 0.005 \\
\hline Limit of detection $\left(\mathrm{nmol} \mathrm{L}^{-1}\right)$ & $5 \mu \mathrm{m}$ filter & 0.011 & 0.030 & 0.365 & 0.001 \\
& $0.45 \mu \mathrm{m}$ filter & 0.026 & 0.046 & 1.190 & 0.001 \\
\hline Recovery CRM $(\%)$ & BCR-414 $(n=10)$ & $88 \pm 7$ & & & $94 \pm 7$ \\
& MESS-4 $(n=5)$ & $98 \pm 14$ & $97 \pm 14$ & $80 \pm 30$ & $110 \pm 18$ \\
& PACS-3 $(n=8)$ & $101 \pm 9$ & $99 \pm 14$ & $91 \pm 34$ & $112 \pm 11$ \\
\hline
\end{tabular}

by biotic uptake (e.g. Sunda and Huntsman, 1983; Peers and Price, 2004), this proxy is only used at depths where biologic activity was negligible (i.e. below $150 \mathrm{~m}$ depth).

Potential temperature $\left(\theta^{\circ}\right)$, salinity $(S)$, and transmissometry data were retrieved from the CTD sensors (CTD SBE911 equipped with a SBE43).

\section{Results}

\subsection{Hydrography setting}

Here, we briefly describe the hydrography encountered during the GEOVIDE section (Fig. 2) as a thorough description is available in García-Ibáñez et al. (2015). At the start of the section, the warm and salty Mediterranean Water (MW, $S=36.50, \theta^{\circ}=11.7^{\circ} \mathrm{C}$ ) was sampled between 600 and $1700 \mathrm{~m}$ in the Iberian Abyssal Plain (IAP). MW resulted from the mixing between the Mediterranean Overflow Water (MOW) plume coming from the Mediterranean Sea and local waters. Surface water above the Iberian Shelf was characterized by low salinity $(S=34.95)$ at stations 2 and 4 compared to surrounding water masses. Close to the seafloor of the Iberian Abyssal Basin, the North East Atlantic Deep Water (NEADW, $S=34.89, \theta^{\circ}=2.0^{\circ} \mathrm{C}$ ) spread northward. The North Atlantic Central Water (NACW, $S>35.60, \theta^{\circ}>12.3^{\circ} \mathrm{C}$ ) was the warmest water mass of the transect and was observed in the subsurface layer of the Western European Basin and Iberian Abyssal Plain. An old Labrador Sea Water (LSW, $S=34.87, \theta^{\circ}=3.0^{\circ} \mathrm{C}$ ) flowed inside the Western European and Icelandic basins, between 1000 and $2500 \mathrm{~m}$ depth.

In the Icelandic Basin, below the old LSW, the IcelandScotland Overflow Water (ISOW, $S=34.98, \theta^{\circ}=2.6^{\circ} \mathrm{C}$ ) spread along the Reykjanes Ridge slope. This cold water, originating from the Arctic, led to the formation of NEADW after mixing with surrounding waters. North Atlantic hydrography was impacted by the northward flowing of the North Atlantic Current (NAC), which carried warm and salty waters from the subtropical area. Due to air-sea interactions and mixing with surrounding water, the NACW is cooled and freshened in the subpolar gyre and is transformed into Subpolar Mode Water (SPMW). The formation of SPMW inside the Icelandic and Irminger basins leads to the formation of regional mode waters: the Iceland Subpolar Mode Water (IcSPMW, $S=35.2, \theta^{\circ}=8.0^{\circ} \mathrm{C}$ ) and the Irminger Subpolar Mode Water (IrSPMW, $S=35.01, \theta^{\circ}=5.0^{\circ} \mathrm{C}$ ), respectively. IcSPMW was a relatively warm water mass with potential temperature up to $7{ }^{\circ} \mathrm{C}$ (García-Ibáñez et al., 2015). Another branch of the NAC mixed with Labrador Current waters to form the relatively fresh Sub-Arctic Intermediate Water (SAIW, $S=<34.8,4.5^{\circ} \mathrm{C}<\theta^{\circ}<6^{\circ} \mathrm{C}$ ).

The Irminger Basin is a complex area with a multitude of water masses. In the middle of the basin, an old LSW, formed 1 year before (Straneo et al., 2003), spread between 500 and $1200 \mathrm{~m}$ depth. Close to the bottom, the Denmark Strait Overflow Water (DSOW, $S=34.91$ ) flowed across the basin. Greenland coastal waters were characterized by low salinity values, down to $S=33$. The strong East Greenland Current (EGC) flowed southward along the Greenland Shelf in the Irminger Basin. At the southern tip of Greenland, this current enters the Labrador Basin along the western coast of Greenland and followed the outline of the basin until the Newfoundland Shelf. In the Labrador Basin, the deep convection of SPMW at $2000 \mathrm{~m}$ was involved in the formation of the LSW $\left(S=34.9, \theta^{\circ}=3.0^{\circ} \mathrm{C}\right.$ ) (Yashayaev and Loder, 2009; García-Ibáñez et al., 2015). Above the Newfoundland Shelf, surface waters were affected by discharge from rivers and ice melting and characterized by extremely low salinity for open ocean waters, below 32 in the first $15 \mathrm{~m}$.

\subsection{Section overview}

Total particulate concentrations spanned a large range of concentrations from below detection (Table 1) to $304 \mathrm{nmol} \mathrm{L}^{-1}$ for PFe, $1544 \mathrm{nmol} \mathrm{L}^{-1}$ for PAl, $3.5 \mathrm{nmol} \mathrm{L}^{-1}$ for PMn, and $402 \mathrm{nmol} \mathrm{L}^{-1}$ for PP. The ranges of concentrations are comparable to other studies recently published (Table 2).

Along the section, $\mathrm{PFe}, \mathrm{PAl}$, and $\mathrm{PMn}$ were predominantly found $(>90 \%)$ in particles larger than $5 \mu \mathrm{m}$, except in surface waters, reflecting a more heterogenous pattern, where $9 \pm 8.6 \%$ of $\mathrm{PFe}, 10.9 \pm 15.4 \%$ of $\mathrm{PAl}, 32.8 \pm 16.6 \%$ of 


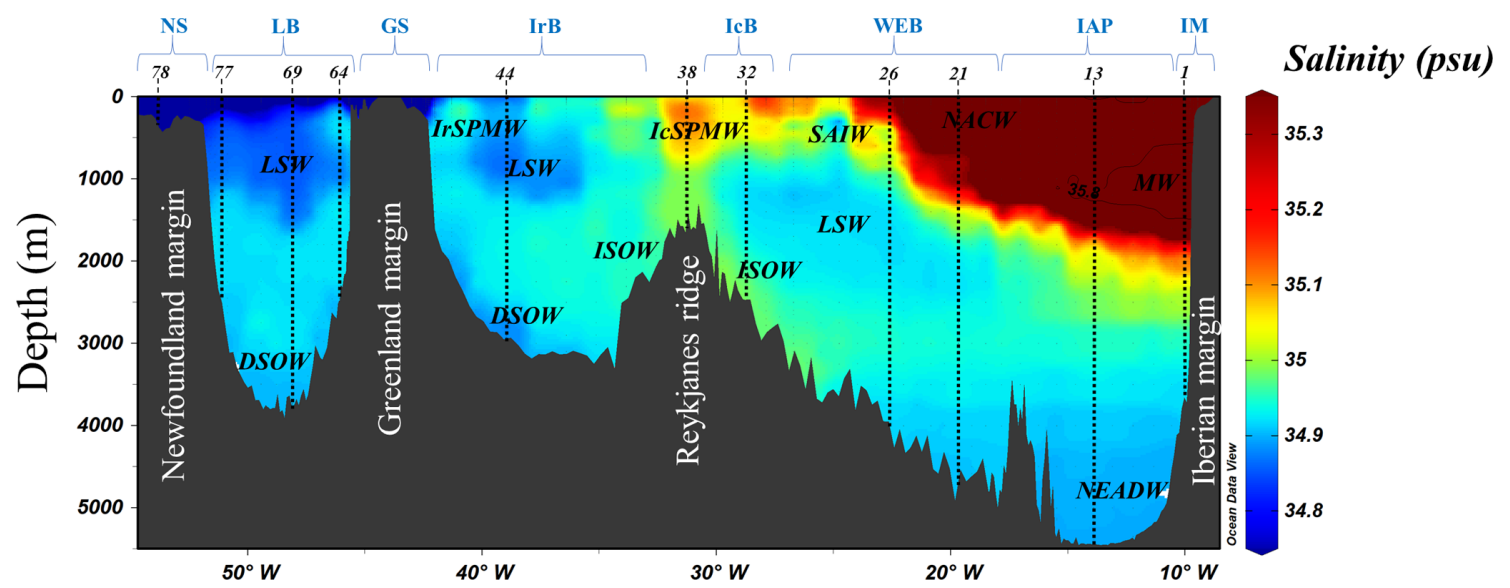

Figure 2. Salinity section during the GEOVIDE cruise with water masses indicated in black italic font. A salinity contour of 35.8 psu has been applied to identify the Mediterranean Water (MW) to the east. From right to left: North East Atlantic Deep Water (NEADW); North Atlantic Central Water (NACW); Labrador Sea Water (LSW); Sub-Arctic Intermediate Water (SAIW); Iceland-Scotland Overflow Water (ISOW); Iceland Sub-Polar Mode Water (IcSPMW); Denmark Strait Overflow Water (DSOW); Irminger Sub-Polar Mode Water (IrSPMW). Station locations are indicated by the numbers above the section and biogeochemical provinces are indicated in blue font above station numbers. This figure was generated using Ocean Data View (Schlitzer, R., Ocean Data View, http://odv.awi.de/, 2017).

Table 2. Concentration (in $\mathrm{nmol} \mathrm{L}^{-1}$ ) of particulate trace elements (PFe, Pal, PMn, and PP) in suspended particles collected in diverse regions of the world's ocean.

\begin{tabular}{|c|c|c|c|c|c|c|c|c|}
\hline Location & Depth range & $\mathrm{PFe}$ & PAl & PMn & $\mathrm{PP}$ & Fraction & Author & Year \\
\hline N. Atlantic $\left(>40^{\circ} \mathrm{N}\right)$ & All & bdl-304 & bdl-1544 & bdl-3.5 & bdl-402 & $>0.45 \mu \mathrm{m}$ & This study & \\
\hline Labrador Sea & $0-250$ & $0.1-1.2$ & $0.1-1.5$ & & & $>53 \mu \mathrm{m}$ & Weinstein and Moran & 2004 \\
\hline Labrador Sea & $0-250$ & 2.5 & 3.6 & 0.05 & & $0.4-10 \mu \mathrm{m}$ & Weinstein and Moran & 2004 \\
\hline N. Atlantic $\left(25-60^{\circ} \mathrm{N}\right)$ & Upper $1000 \mathrm{~m}$ & $0.29-1.71$ & $0.2-19.7$ & & & $0.4 \mu \mathrm{m}$ & Barrett et al. & 2012 \\
\hline N. Atlantic & All & $0-938$ & $0-3600$ & & & $0.8-51 \mu \mathrm{m}$ & Ohnemus and Lam & 2015 \\
\hline Gulf of Maine & $0-300$ & 34.8 & 109 & & & $>0.4 \mu \mathrm{m}$ & Weinstein and Moran & 2004 \\
\hline Eastern tropical N.A. & $0-200$ & & $0.59-17.7$ & & & $>0.2 \mu \mathrm{m}$ & Dammshäuser et al. & 2013 \\
\hline Eastern tropical N.A. & $0-600$ & ND-12 & & & & $1-51 \mu \mathrm{m}$ & Lam et al. & 2012 \\
\hline Sub-tropical N.A. & All & ND-140 & ND-800 & & & $>0.45 \mu \mathrm{m}$ & Milne et al. & 2017 \\
\hline Meridional Atlantic & $0-200$ & & $0.35-16.1$ & & & $>0.2 \mu \mathrm{m}$ & Dammshäuser et al. & 2013 \\
\hline Northeastern Pacific & $0-3557$ & & $0.0-54.2$ & & & $1-53 \mu \mathrm{m}$ & Sherrell et al. & 1998 \\
\hline Eastern tropical S. Pacific & All & bdl-159 & bdl-162 & bdl-8.7 & bdl-983 & $>0.8 \mu \mathrm{m}$ & Lee et al. & 2017 \\
\hline South Georgia Shelf & All & $0.87-267$ & $0.6-195$ & $0.01-3.85$ & & $>1 \mu \mathrm{m}$ & Schlosser et al. & 2018 \\
\hline Southern Ocean & $30-340$ & $0.15-13.2$ & $0.11-25.5$ & & & $>53 \mu \mathrm{m}$ & Planquette et al. & 2009 \\
\hline East Antarctic & Surface & & $0.02-10.67$ & $0.01-0.14$ & & $>0.2 \mu \mathrm{m}$ & Lannuzel et al. & 2011 \\
\hline East Antarctic & Fast ice & $43-10385$ & $121-31372$ & $1-307$ & & $>0.2 \mu \mathrm{m}$ & Lannuzel et al. & 2014 \\
\hline Ross Sea & All & $0.68-57.3$ & ND-185 & ND-1.4 & $5.4-404$ & $>0.4 \mu \mathrm{m}$ & Marsay et al. & 2017 \\
\hline
\end{tabular}

Bdl: below detection limit; ND: non-determined; N.A.: North Atlantic.

PMn, and $38.8 \pm 8.6 \%$ of PP were hosted by smaller particles $(0.45-5 \mu \mathrm{m})$. Data are shown in Fig. 3.

\subsection{Open Ocean stations: from the Iberian Abyssal Plain to the Labrador Basin}

This concerns all stations from stations 11 to 77 , with the exception of stations 53, 56, and 61, which were sampled close to the Greenland coast (Fig. 1). Particulate iron concentration profiles showed identical patterns at all the open ocean stations encountered along the section. Median PFe was low at $0.25 \mathrm{nmol} \mathrm{L}^{-1}$ within the first $100 \mathrm{~m}$ and steadily increased with depth. However, at two stations, elevated concentrations were determined in the upper $100 \mathrm{~m}$, up to $4.4 \mathrm{nmol} \mathrm{L}^{-1}$ at station 77 at $40 \mathrm{~m}$ depth and $7 \mathrm{nmol} \mathrm{L}^{-1}$ at station 63 between 70 and $100 \mathrm{~m}$ depth. PFe concentrations gradually increased with depth, with a median PFe of $1.74 \mathrm{nmol} \mathrm{L}^{-1}$ below $1000 \mathrm{~m}$. Close to the seafloor of some stations $(26,29$, $32,34,49,60$, and 71), high concentrations of PFe were observed, up to $88 \mathrm{nmol} \mathrm{L}^{-1}$ (station 71 at $3736 \mathrm{~m}$ ). These high PFe values were associated with low beam transmissometry values $\leq 97 \%$. 

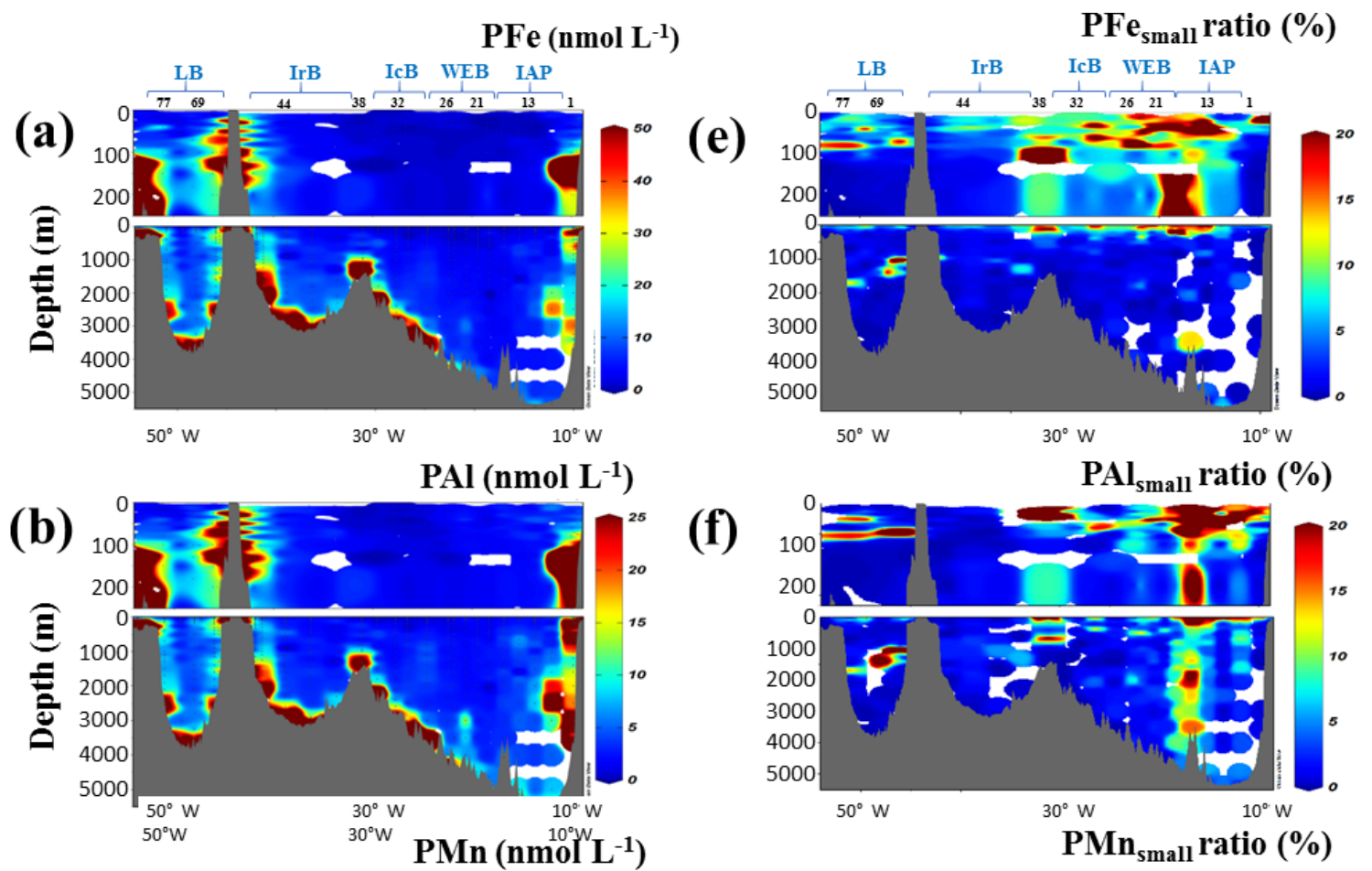

(f)
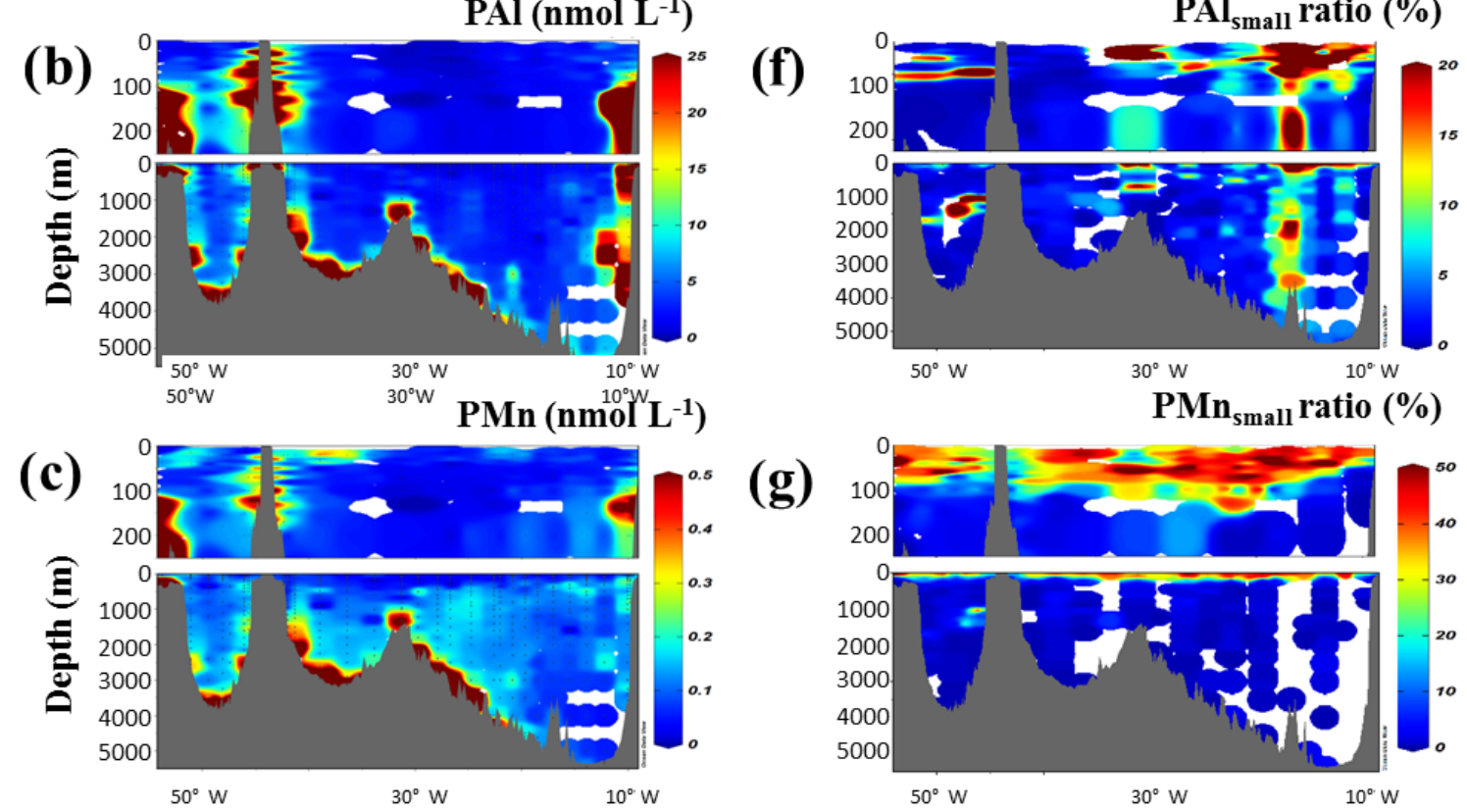

(g)
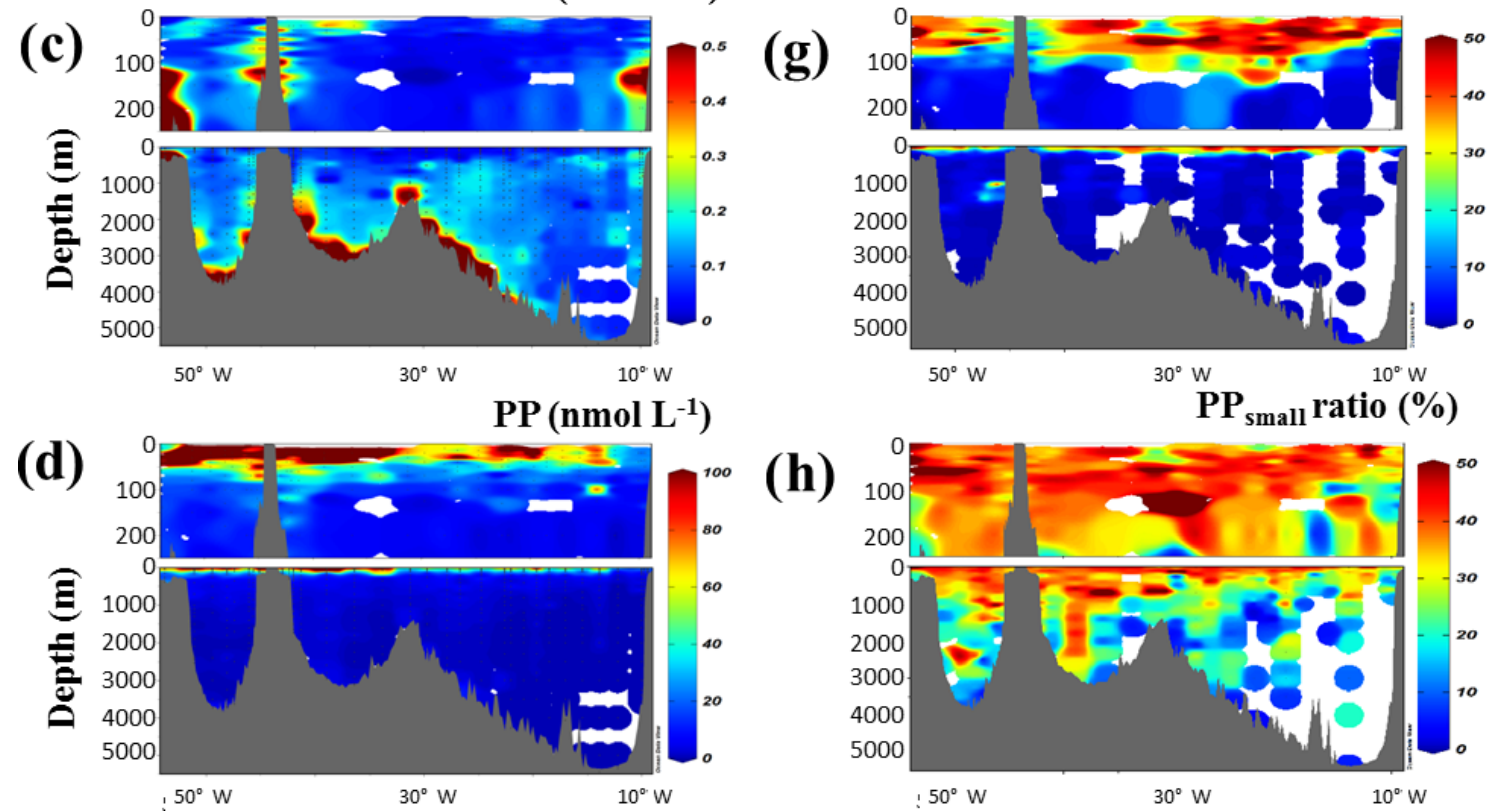

Figure 3. (a-d) Distribution of total particulate (a) iron (PFe), (b) aluminium (PAl), (c) manganese (PMn), and (d) phosphorus (PP) concentrations $\left(\mathrm{nmol} \mathrm{L}^{-1}\right)$ in the first $250 \mathrm{~m}$ and the entire water column along the GEOVIDE section in the North Atlantic Ocean. Right panel: contribution of the small size fraction $(0.45-5 \mu \mathrm{m})$ expressed as a percentage (\%) of the total concentration of (e) PFe, (f) PAl, (g) PMn, and (h) PP. Station IDs and biogeochemical regions are indicated on top of panels (a) and (e). This figure was generated using Ocean Data View (Schlitzer, R., Ocean Data View, http://odv.awi.de/, 2017).

Particulate aluminium and manganese profiles were similar to PFe profiles, with low concentrations measured in the first $100 \mathrm{~m}\left(1.88 \mathrm{nmol} \mathrm{L}^{-1}\right.$ and $55 \mathrm{pmol} \mathrm{L}^{-1}$, respectively) which increased towards the seafloor. Close to the seafloor, high concentrations were determined at the same stations cited above for PFe, with a maximum of 264 and $3.5 \mathrm{nmol} \mathrm{L}^{-1}$ for PAl and PMn, respectively, at station 71 (Table S1 in the Supplement). The highest particulate phosphorus concentrations were in the uppermost $50 \mathrm{~m}$, with a median value of $66 \mathrm{nmol} \mathrm{L}^{-1}$. Below $200 \mathrm{~m}$ depth PP con- 
centrations decreased to values below $10 \mathrm{nmol} \mathrm{L}^{-1}$. Interbasins differences were observed within surface samples, with median PP concentrations being higher in the Irminger Basin $\left(127 \mathrm{nmol} \mathrm{L}^{-1}\right)$ than in the Iberian Abyssal Plain (28 $\mathrm{nmol} \mathrm{L}^{-1}$ ) (Fig. 3).

Finally, above the Reykjanes Ridge, PP, PMn, PAl, and $\mathrm{PFe}$ concentrations were in the same range as the surrounding open ocean stations. However, close to the seafloor, high concentrations were measured, with $\mathrm{PFe}, \mathrm{PAl}$, and $\mathrm{PMn}$ reaching $16.2,28.8$, and $0.51 \mathrm{nmol} \mathrm{L}^{-1}$ at $1354 \mathrm{~m}$ depth, respectively (Fig. 3 and Table S1 in the Supplement).

\subsection{Margins and shelves: Iberian margin (stations 1 to 4), Greenland coast (stations 53, 56, and 61), and Newfoundland Shelf (station78)}

The Iberian margin was characterized by low beam transmissometry values at station $2(88 \%$ at $140 \mathrm{~m}$ depth, Fig. $4 \mathrm{a})$, suggesting high particle concentrations. Particulate iron concentrations varied from 0.02 to $304 \mathrm{nmol} \mathrm{L}^{-1}$. Within the first $50 \mathrm{~m}$, PFe concentrations decreased towards the shelf break where PFe dropped from $2.53 \mathrm{nmol} \mathrm{L}^{-1}$ (station 2) to $0.8 \mathrm{nmol} \mathrm{L}^{-1}$ (station 1). At all three stations, PFe concentrations increased with depth and reached a maximum close to the seafloor. For example, $300 \mathrm{nmol} \mathrm{L}^{-1}$ of PFe was determined at $138.5 \mathrm{~m}$ depth at station 2. Lithogenic tracers, such as PAl or PMn, presented similar profiles to PFe with concentrations ranging from 0.11 and $1544 \mathrm{nmol} \mathrm{L}^{-1}$, and from below the detection limit to $2.51 \mathrm{nmol} \mathrm{L}^{-1}$, respectively (Fig. 3, Table S1). Total particulate phosphorus concentrations were relatively low in surface waters, ranging from values below detection to $38 \mathrm{nmol} \mathrm{L}^{-1}$; concentrations decreased with depth and were less than $0.7 \mathrm{nmol} \mathrm{L}^{-1}$ below $1000 \mathrm{~m}$ depth.

In the vicinity of the Greenland Shelf, PFe concentrations had a high median value of $10.8 \mathrm{nmol} \mathrm{L}^{-1}$ and were associated with high median PAl and PMn concentrations of 32.3 and $0.44 \mathrm{nmol} \mathrm{L}^{-1}$, respectively. Concentrations of $\mathrm{PP}$ were high at the surface with a value of $197 \mathrm{nmol} \mathrm{L}^{-1}$ at $25 \mathrm{~m}$ depth of station 61 . Then, PP concentrations decreased strongly, to less than $30 \mathrm{nmol} \mathrm{L}^{-1}$ below $100 \mathrm{~m}$ depth. Furthermore, beam transmissometry values in surface waters at these three stations were the lowest of the entire section, with values below $85 \%$ (Fig. 4a).

Close to the Newfoundland margin, surface waters displayed a small load of particulate trace metals as PFe, $\mathrm{PAl}$, and PMn concentrations were below $0.8,2$, and $0.15 \mathrm{nmol} \mathrm{L}^{-1}$, respectively. Then, close to the bottom of station 78 , at $371 \mathrm{~m}$ depth, beam transmissometry values dropped to $94 \%$ (Fig. 4a) and were associated with extremely high concentrations of $\mathrm{PFe}=168 \mathrm{nmol} \mathrm{L}^{-1}, \mathrm{PAl}=$ $559 \mathrm{nmol} \mathrm{L}^{-1}$, and $\mathrm{PMn}=2 \mathrm{nmol} \mathrm{L}^{-1}$. Total PP concentrations in the first $50 \mathrm{~m}$ ranged from 35 to $97 \mathrm{nmol} \mathrm{L}^{-1}$. Below $50 \mathrm{~m}$, PP remained relatively high with values up to $16 \mathrm{nmol} \mathrm{L}^{-1}$ throughout the water column (Fig. 3 and Table S1).

\section{Discussion}

Our goal was to investigate mechanisms that drive the distribution of PFe in the North Atlantic, in particular the different routes of supply and removal. Possible sources of PFe include lateral advection offshore from margins, atmospheric inputs, continental run-off, melting glaciers and icebergs, resuspended sediments, hydrothermal inputs, and biological uptake. Removal processes include remineralization, dissolution processes, and sediment burial.

In the following sections, we examine each of these sources and processes, explore the evidence for their relative importance, and use compositional data to estimate the particle types and host phases for iron and associated elements.

\subsection{Analysis of the principal factors controlling variance: near-ubiquitous influence of crustal particles in the water column}

Positive matrix factorization analysis (Fig. 5) was undertaken on the entire dataset; in consequence, the factors described below are highly influenced by the major variations of particulate element concentrations (usually at the interfaces, i.e. margin, seafloor, surface layer). The first factor is characterized by lithogenic elements, representing $86.8 \%$ of the variance of PFe, $75.8 \%$ of PAl, and $90.5 \%$ of PTi. The second factor is correlated with both $\mathrm{Mn}$ and $\mathrm{Pb}$ and explains no less than $76.5 \%$ and $77.0 \%$ of their respective variances. Ohnemus and Lam (2015) observed this relationship between manganese and lead particles and explained it by the co-transport on Mn oxides (Boyle et al., 2005). The formation of barite explains the third factor and constrained $87.7 \%$ of the $\mathrm{Ba}$ variance in the studied regions. Biogenic barite accumulation within the mesopelagic layer is related to bacterial activity and remineralization of biogenic material (Lemaitre et al., 2018). A biogenic component is the fourth factor and explained most of the PP variance, $83.7 \%$. The micronutrient trace metals, copper, cobalt, and zinc, had more than a quarter of their variances influenced by this factor. Note that the biogenic contribution to $\mathrm{PFe}$ and other trace elements will be discussed in another paper (Planquette et al., 2019).

These results indicate that along the GA01 section, $\mathrm{PFe}$ distributions were predominantly controlled by lithogenic material and to a smaller extent by remineralization processes (PMF, factor $3=4.1 \%$ ). This does not rule out some biogenic influences on PFe distribution, especially in the surface, but its contribution is most likely obscured by the high lithogenic contribution.

To further investigate the influence of crustal material on the distribution of PFe, it is instructive to examine the distribution of the PFe to PAl molar ratio, and the resulting $\% \mathrm{PFe}_{\text {litho }}$ (see Sect. 2.6 for a definition of this parameter) along the section (Figs. 6 and 7). Overall, the estimated lithogenic contribution to $\mathrm{PFe}$ varies from $25 \%$ (west of the 

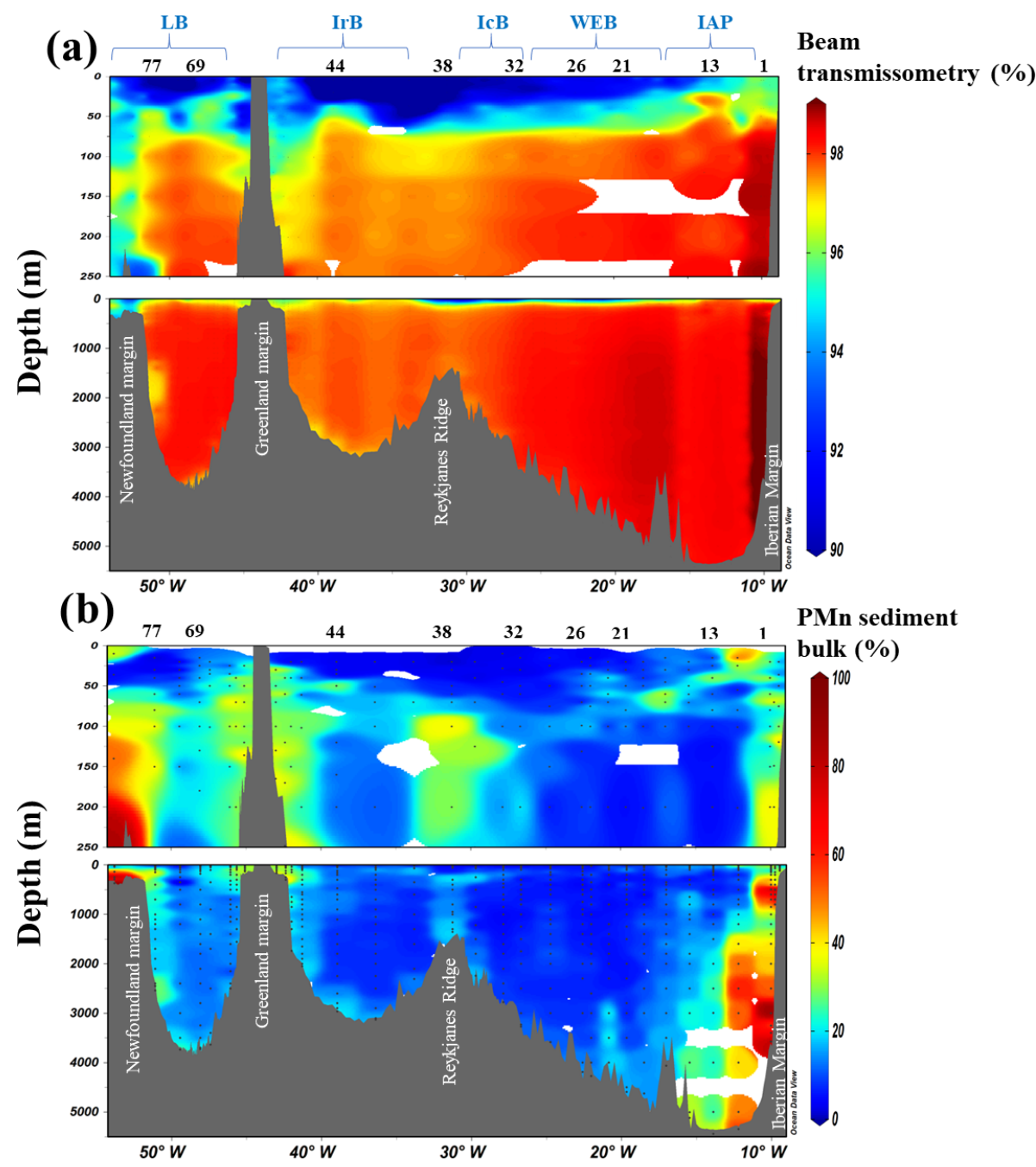

Figure 4. Section of derived contributions of sedimentary inputs along the GA01 section with (a) beam transmissometry (\%) and (b) manganese bulk sediment proxy (\%) based on Eq. (3). Station IDs and biogeochemical region are indicated above section (a) in black numbers and blue letters, respectively. This figure was generated using Ocean Data View (Schlitzer, R., Ocean Data View, http://odv.awi.de/, 2017).

Irminger Basin, station $60,950 \mathrm{~m}$ depth) to $100 \%$ at stations located within the Western European Basin. Note that $100 \%$ of estimated lithogenic PFe does not necessarily mean that biogenic particles are absent; they may just be masked by the dominance of lithogenic particles. Important interbasin variations are observed along the section (Fig. 6). The IAP and WEB displayed high median values of the proxy $\% \mathrm{PFe}_{\text {litho }}, 90 \%$ (Fig. 6b); this could be linked to the lateral advection of iron-rich lithogenic particles sourced from the Iberian margin and to atmospheric inputs (Shelley et al., 2017). Then, between stations 26 and 29 , the $\% \mathrm{PFe}_{\text {litho }}$ proxy values dramatically decreased, and reached values less than $55 \%$ in the Iceland, Irminger, and Labrador basins (Fig. 6b). This feature is likely associated with the presence of the SubArctic Front located between 49.5 and $51^{\circ} \mathrm{N}$ latitude and 23.5 and $22^{\circ} \mathrm{W}$ longitude (Zunino et al., 2017). Indeed, this front which separates cold and fresh water of subpolar origin from warm and salty water of subtropical origin was clearly identifiable by the steep gradient of the isohalines between stations 26 and 29, salinity dropping from 35.34 to 35.01 (Fig. 2). Lower \% $\mathrm{PFe}_{\text {litho }}$ proxy values could be associated with higher proportions of $\mathrm{PFe}$ from biogenic origin, especially in the case of the LSW.

\subsection{Tracking the different inputs of particulate iron}

\subsubsection{Inputs at margins: Iberian, Greenland, and Newfoundland}

Inputs of iron from continental margin sediments supporting the high productivity found in shallow coastal regions have been demonstrated in the past (e.g. Elrod et al., 2004; Ussher et al., 2007; Cullen et al., 2009; Jeandel et al., 2011) and sometimes were shown to be advected at great distances from the coast (e.g. Lam and Bishop, 2008). In the following 


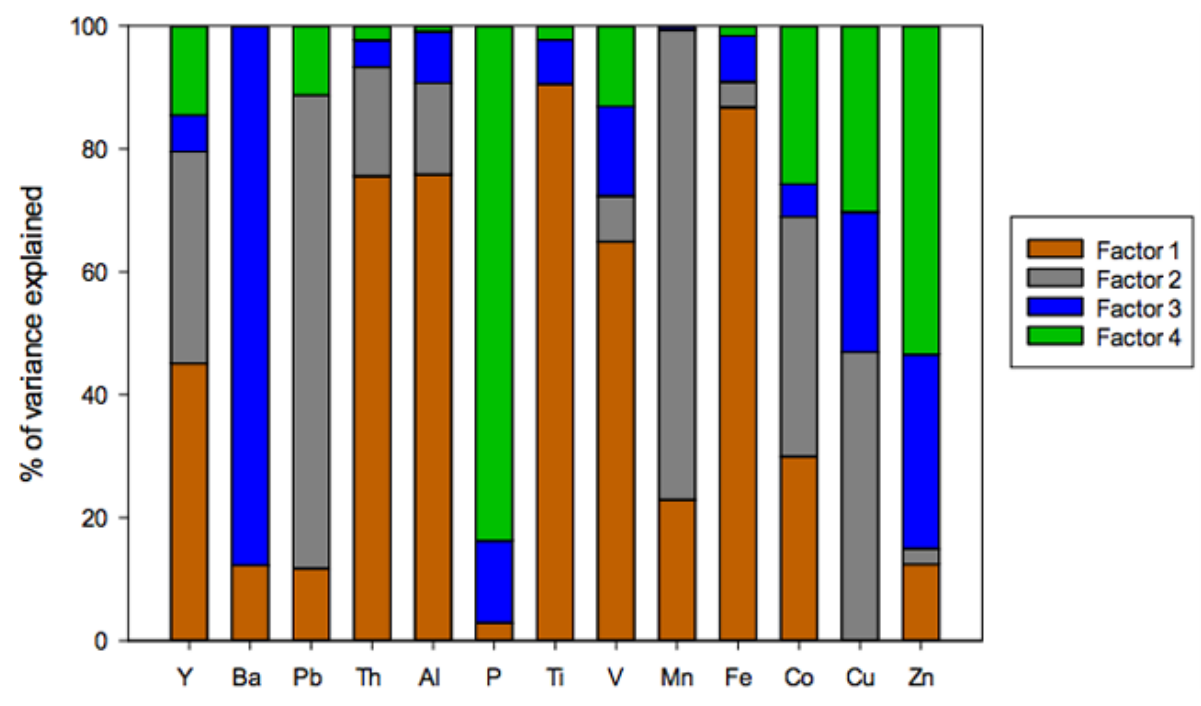

Figure 5. Factor fingerprint of the positive matrix factorization conducted on 445 particle samples collected along the GA01 section. The four main factors influencing the particulate trace element variance are represented in a stacked bar chart of the percentage of variance explained per element. Factor 1 is dominated by the lithogenic elements, e.g. Th, $\mathrm{Al}$, Ti, and Fe. Factor 2 is associated with $\mathrm{Pb}$ and $\mathrm{Mn}$ variances. Biogenic barite formation mainly influences factor 3. Factor 4 is dominated by biogenic elements, e.g. P, Co, Cu, and $\mathrm{Zn}$.

section, we will investigate these possible sources in proximity to the different margins encountered.

\section{The Iberian margin}

The Iberian margin was an important source of lithogenicderived iron-rich particles to the Atlantic Ocean during GEOVIDE; shelf resuspension impacts were perceptible up to $280 \mathrm{~km}$ from the margin (station 11) in the Iberian Abyssal Plain (Fig. 8).

On the shelf, at station 2, high sediment resuspension resulted in the low beam transmissometry value $(87.6 \%)$ in the immediate vicinity of the seafloor (153 m depth). This sediment resuspension led to an extensive input of lithogenic particles within the water column associated with high concentrations of PFe $\left(304 \mathrm{nmol} \mathrm{L}^{-1}\right)$, PAl $\left(1500 \mathrm{nmol} \mathrm{L}^{-1}\right)$, and PMn $\left(2.5 \mathrm{nmol} \mathrm{L}^{-1}\right)$ (Fig. 3, Table S1). Moreover, $100 \%$ of $\mathrm{PFe}$ was estimated to have a lithogenic origin (Fig. 8b), while $100 \%$ of the PMn was estimated to be the result of a recent sediment resuspension according to the $\% \mathrm{PFe}_{\text {litho }}$ and "\%bulk sediment Mn" proxies (Fig. 8b, c), confirming the resuspended particle input. In addition, ADCP data acquired during GEOVIDE (Zunino et al., 2017) and several other studies have reported an intense current spreading northward coming from the Strait of Gibraltar and the Mediterranean Sea, leading to the strong resuspension of benthic sediments above the Iberian Shelf (e.g. Eittreim et al., 1976; Biscaye and Eittreim, 1977; Spinrad et al., 1983; McCave and Hall, 2002).

At distance from the shelf, within the Iberian Abyssal Plain, an important lateral advection of PFe from the margin was observable (Fig. 8a). These lateral inputs oc- curred at two depth ranges: between 400 and $1000 \mathrm{~m}$ as seen at stations 4 and 1 , with $\mathrm{PFe}$ concentrations reaching $4 \mathrm{nmol} \mathrm{L}^{-1}$, and between $2500 \mathrm{~m}$ and the bottom $(3575 \mathrm{~m})$ of station 1, with PFe concentrations reaching $3.5 \mathrm{nmol} \mathrm{L}^{-1}$. While $100 \%$ of PFe had a lithogenic signature, the sedimentary source input estimation decreased, between $40 \%$ and $90 \%$ of the PMn (Fig. 8b). Transport of lithogenic particles was observable until station $11\left(12.2^{\circ} \mathrm{W}\right)$ at $2500 \mathrm{~m}$, where $\mathrm{PFe}$ concentration was $7.74 \mathrm{nmol} \mathrm{L}^{-1}$ and $60 \%$ of PMn had a sedimentary origin (Fig. 4). It is noteworthy that no increase in PFe, PMn, or PAl was observed between 500 and $2000 \mathrm{~m}$ depth, where the MOW spreads (García-Ibáñez et al., 2015). This is consistent with the observed dissolved iron (DFe) concentrations (Tonnard et al., 2018, this issue), yet in contrast to dissolved aluminium (DAl) concentrations (Menzel Barraqueta et al., 2018, this issue), which were high in the MOW, and with the study of Ohnemus and Lam (2015) that reported a maximum $\mathrm{PFe}$ concentration at $695 \mathrm{~m}$ depth associated with the particle-rich Mediterranean Overflow Water (Eittreim et al., 1976) in the IAP. However, their station was located further south of our station 1 . The shallower inputs observed at stations 1 and 4 could therefore be attributed to sediment resuspension from the Iberian margin and nepheloid layer at depth for station 1.

Surface coastal waters of the Iberian Shelf are impacted by the runoff for the Tagus River, which is characterized by high suspended matter discharges, ranging between 0.4 and $1 \times 10^{6}$ ton $\mathrm{yr}^{-1}$, and with a high anthropogenic trace element signature (Jouanneau et al., 1998). During the GEOVIDE section, the freshwater input was observable at stations 1,2 , and 4 in the first $20 \mathrm{~m}$; salinity was below 35.2 , while surrounding water masses had salinity up to 35.7. 

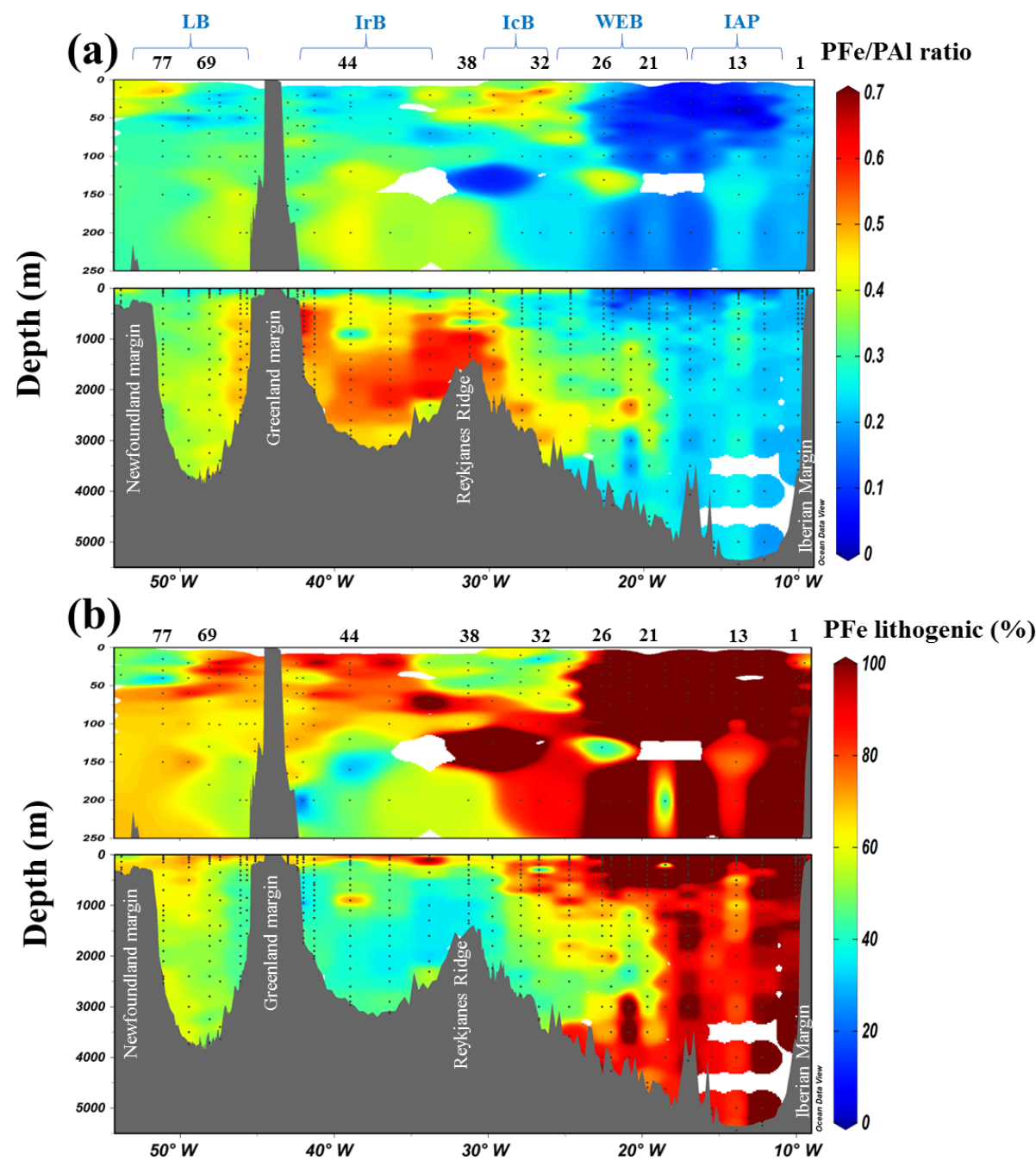

Figure 6. (a) Section of the PFe to PAl molar ratio $\left(\mathrm{mol} \mathrm{mol}^{-1}\right)$ during the GEOVIDE cruise (GA01) and (b) contribution (\%) of lithogenic particulate iron $\left(\mathrm{PFe}_{\text {litho }}\right.$ ) based on Eq. (1). Station IDs and biogeochemical provinces are indicated above each section in black numbers and blue letters, respectively. This figure was generated using Ocean Data View (Schlitzer, R., Ocean Data View, http://odv.awi.de/, 2017).

Within the freshwater plume, particulate concentrations were high at station 2, with a PFe of $1.83 \mathrm{nmol} \mathrm{L}^{-1}$. Further away from the coast, the particulate concentrations remained low at $20 \mathrm{~m}$ depth, with PFe, PAl, and PMn concentrations of 0.77 , 3.5 , and $0.04 \mathrm{nmol} \mathrm{L}^{-1}$, respectively, at station 1 . The low expansion of the Tagus plume is likely due to the rapid settling of suspended matter. Indeed, our coastal station 2 was located approximately $50 \mathrm{~km}$ from the Iberian coast, whereas the surface particle load can only be observed at a maximum distance of $30 \mathrm{~km}$ from the Tagus estuary (Jouanneau et al., 1998). Overall, the Iberian margin appears to be an important source of lithogenic-derived iron-rich particles to the Atlantic Ocean.

\section{South Greenland}

During GEOVIDE, the Greenland shelves were a source of particulate-rich meteoric water leading to a transfer of $\mathrm{DFe}$ to PFe by enhanced biological activity. Indeed, both the East (station 53) and West (station 61) Greenland shelves had high concentrations of particles (beam transmissometry of $83 \%$, Fig. 4a) and particulate trace elements, reaching $22.1 \mathrm{nmol} \mathrm{L}^{-1}$ (at $100 \mathrm{~m}$ depth) and $18.7 \mathrm{nmol} \mathrm{L}^{-1}$ (at $136 \mathrm{~m}$ depth) of $\mathrm{PFe}$, respectively. Several studies have already demonstrated the importance of icebergs and sea-ice melting as sources of dissolved and particulate iron (e.g. Raiswell et al., 2008; Planquette et al., 2011; van der Merwe et al., 2011a, b). The Greenland Shelf is highly influenced by external freshwater inputs such as sea-ice melting or riverine runoff (Fragoso et al., 2016), which are important sources of iron to the Greenland Shelf (Statham et al., 


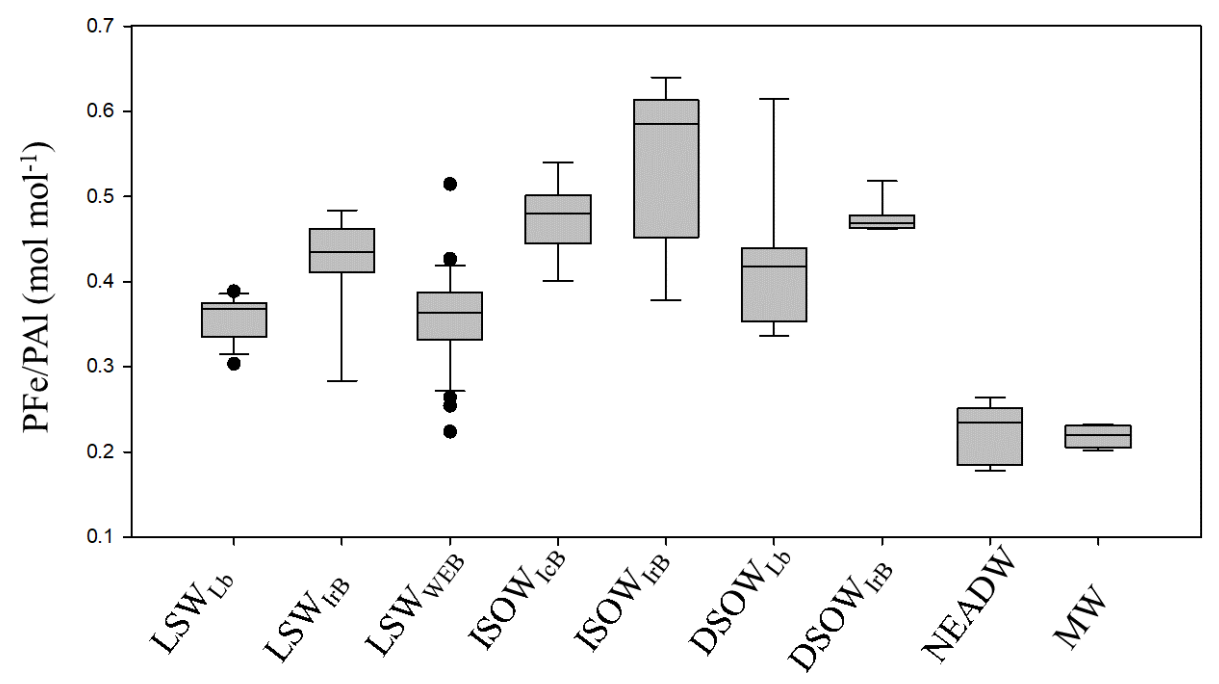

Figure 7. Box and whisker diagram of the PFe/PAl molar ratio in nine water masses sampled along the GA01 section in the North Atlantic Ocean. Water masses are defined in Sect. 3.1 and in Fig. 2. The PFe/PAl median values for each water mass with the biogeochemical provinces in subscript were as follows: $\mathrm{LSW}_{\mathrm{LB}}=0.37 ; \mathrm{LSW}_{\mathrm{IrB}}=0.44 ; \mathrm{LSW}_{\mathrm{WEB}}=0.36 ; \mathrm{ISOW}_{\mathrm{IcB}}=0.48 ; \mathrm{ISOW}_{\mathrm{IrB}}=0.58$; $\mathrm{DSOW}_{\mathrm{LB}}=0.42 ; \mathrm{DSOW}_{\mathrm{IrB}}=0.47 ; \mathrm{NEADW}_{\mathrm{IAP}}=0.23 ; \mathrm{MW}=0.22 \mathrm{~mol} \mathrm{~mol}^{-1}$. The difference in PFe$/ \mathrm{PAl}$ between water masses is statistically significant (Kruskal-Wallis test; $p=<0.001$ excluding water masses for which we had fewer than five data points for PFe/PAl). Note that the UCC PFe/PAl ratio reported from Taylor and McLennan (1995) is $0.21 \mathrm{~mol} \mathrm{~mol}^{-1}$.

2008; Bhatia et al., 2013; Hawkings et al., 2014). During the cruise, the relative freshwater observed $(S<33$ psu) within the first $25 \mathrm{~m}$ of stations 53 and 61 was associated with high PFe $\left(19 \mathrm{nmol} \mathrm{L}^{-1}\right), \operatorname{PAl}\left(61 \mathrm{nmol} \mathrm{L}^{-1}\right)$, PMn $\left(0.6 \mathrm{nmol} \mathrm{L}^{-1}\right)$, and low beam transmissometry $(\leq 85 \%)$ (Fig. $4 \mathrm{a}$ and Table S1). The associated particles were enriched in iron compared to aluminium, as the $\mathrm{PFe} / \mathrm{PAl}$ ratio was 0.3 within the meteoric water plume. The high PP concentrations (reaching $197 \mathrm{nmol} \mathrm{L}^{-1}$ ) resulting from high biological production (Chl $a=6.21 \mathrm{mg} \mathrm{m}^{-3}$ at $24 \mathrm{~m}$ at station 61), induced by the supply of bioavailable dissolved iron (surface DFe of $0.79 \mathrm{nM}$ at station 61) from meteoric water (Raiswell et al., 2008; Statham et al., 2008; Tonnard et al., 2018), led to a transfer of DFe to the particulate phase. This is in line with the finding that around $30 \%$ of PFe had a non-lithogenic origin. In addition, only $40 \%$ of PMn originated from resuspended sediments. Interestingly, these two proxies remained constant from the seafloor to the surface (station 49, Fig. 8), with around $25 \%$ of the PMn of sedimentary origin, which could be due to important mixing occurring on the shelf. The lithogenic PFe could result from the release of PFe from Greenland bedrock captured during the ice sheet formation on land.

The spatial extent of the off-shelf lateral transport of particles was not important on the eastern Greenland coast. Indeed, no visible increase in particulate trace metal concentrations was visible at the first station off-shelf, station 60 (Fig. 8), except at $1000 \mathrm{~m}$ depth, where a strong increase (up to $90 \%$ ) in sedimentary PMn was seen. This is probably due to the East Greenland Coastal Current (EGCC) that was located at station 53 which constrained these inputs, while stations 56 and 60 were under the influence of another strong current, the East Greenland-Irminger Current (EGIC) (Zunino et al., 2017). To the west of the Greenland margin, lateral transport of particles was slightly more important. Noticeable concentrations of particulate lithogenic elements were observable until station 64 located $125 \mathrm{~km}$ away from shoreline. These particles had a decreased PFe lithogenic contribution $(50 \%)$ with a similar $(25 \%)$ sedimentary PMn content than closer to the margin (Fig. 8b, c). The increasing nature of non-lithogenic $\mathrm{PFe}$ is linked to the bloom in surface waters $\left(\mathrm{PFe} / \mathrm{PAl}\right.$ ratio of $0.30 \mathrm{~mol} \mathrm{~mol}^{-1}$, $\mathrm{PP}$ of $197 \mathrm{nmol} \mathrm{L}^{-1}$, and Chl $a$ concentration of $6.21 \mathrm{mg} \mathrm{m}^{-3}$ at station 61), with the gravitational settling of biogenic PFe.

Therefore, particles newly resuspended from Greenland sediments are an important source, representing around onethird of the pMn pool, combined with surface inputs such as riverine runoff and/or ice melting that are delivering particles on the shelf, and also biological production. Unlike the Iberian Shelf, the Greenland margin was not an important provider of particulate metals inside the Irminger and Labrador basins, due to the circulation that constrained the extent of the margin plume.

\section{The Newfoundland Shelf}

Previous studies have already described the influence of freshwater on the Newfoundland Shelf from the Hudson Strait and/or Canadian Arctic Archipelago (Yashayaev, 2007; Fragoso et al., 2016). Yashayaev (2007) also monitored 


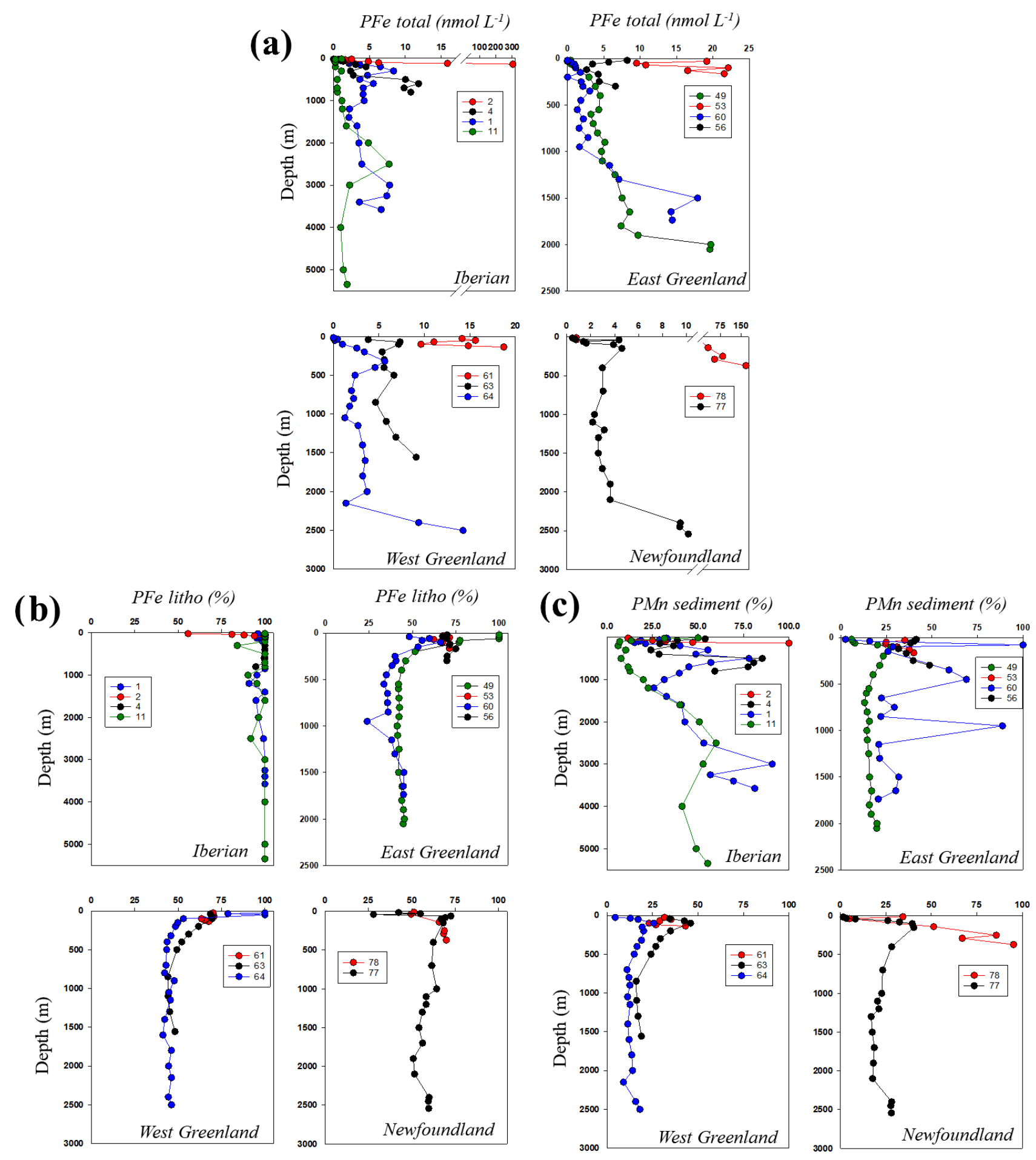

Figure 8. Vertical profiles of (a) $\mathrm{PFe}\left(\mathrm{nmol} \mathrm{L}^{-1}\right)$, (b) lithogenic proportion of particulate iron $\left(\mathrm{PFe}_{\text {litho }}\right.$ \%), and (c) sedimentary proportion of particulate manganese (PMn sediment, \%) at the Iberian, East-West Greenland, and Newfoundland margins.

strong resuspension of sediments associated with the spreading of the Labrador Current along the West Labrador margin.

Close to the Newfoundland coastline, at station 78, high freshwater discharge ( $\leq 32 \mathrm{psu}$ ) was observed in surface waters (Benetti et al., 2017). Interestingly, these freshwater sig- natures were not associated with elevated particulate trace metal concentrations. Distance of meteoric water sources implied a long travel time for the water to spread through the Labrador Basin to our sampling stations. Along the journey, 
particles present originally may have been removed from the water column by gravitational settling.

The proportion of lithogenic PFe was relatively high and constant throughout the water column, with a median value of $70 \%$. At station 78, $95 \%$ of the PMn had a sedimentary origin close to the seafloor $(371 \mathrm{~m})$. The spreading of the recent sediment resuspension was observable until $140 \mathrm{~m}$ depth where the contribution of sedimentary Mn was still $51 \%$ (Fig. 8c, Table S2). This could correspond to an intense nepheloid layer as previously reported by Biscaye and Eittreim (1977) (see also Sect. 3.3.2). The high PFe concentration $\left(184 \mathrm{nmol} \mathrm{L}^{-1}\right.$, station $78,371 \mathrm{~m}$ depth, Fig. $\left.8 \mathrm{~b}\right)$ associated with a high percentage of sedimentary PMn (95\%) observed at the bottom of this station was therefore the result of an important resuspension of shelf sediments. This was confirmed with low transmissometry values of $95 \%$ (Fig. 4a).

Along the GEOVIDE section, continental shelves provided an important load of particles to the surrounding water column. The three margins sampled during GEOVIDE behaved very differently; the Iberian margin discharged high quantities of lithogenic particles far from the coast, while the Greenland and Newfoundland margins did not reveal important $\mathrm{PFe}$ concentrations. Spreading of particles is tightly linked to hydrodynamic conditions, which in the case of the Greenland margin prevented long-distance seeding of $\mathrm{PFe}$. Moreover, each margin showed a specific $\mathrm{PFe} / \mathrm{PAl}$ ratio (Fig. 9) indicating different composition of the resuspended particles. Resuspended particles represent the composition of sediment at the margin if redox transformations of iron and aluminium are considered negligible under these circumstances. Differences between margins were due to the presence of non-crustal particles, either biogenic or authigenic. Biological production in surface waters and authigenic formation of iron hydroxide produced particles with a higher $\mathrm{PFe} / \mathrm{PAl}$ content and their export through the water column to the sediment increased the $\mathrm{PFe} / \mathrm{PAl}$ ratio at depth. Regions where biological production is intense such as in the vicinity of Newfoundland presented higher PFe/PAl ratios of resuspended benthic particles.

\subsubsection{Benthic resuspended sediments}

Along the GEOVIDE section, benthic nepheloid layers (BNLs) provided high concentrations of particulate trace elements to the deep open ocean, contributing significantly to the total budget of iron. BNLs were observable in each province, although intensities varied (Figs. 3 and 10).

In BNLs located within the WEB, PFe concentrations reached up to $10 \mathrm{nmol} \mathrm{L}^{-1}$ (stations 26 and 29, Fig. 10a; Table S1). These concentrations were lower than PFe concentrations in BNLs from the Icelandic (stations 32 and 34), Irminger (stations 42 and 44), and Labrador basins (stations 68,69 , and 71), where benthic resuspension led to $\mathrm{PFe}$ concentrations higher than $40 \mathrm{nmol} \mathrm{L}^{-1}$, even reaching $89 \mathrm{nmol} \mathrm{L}^{-1}$ at the bottom of station 71 (3736 m depth).

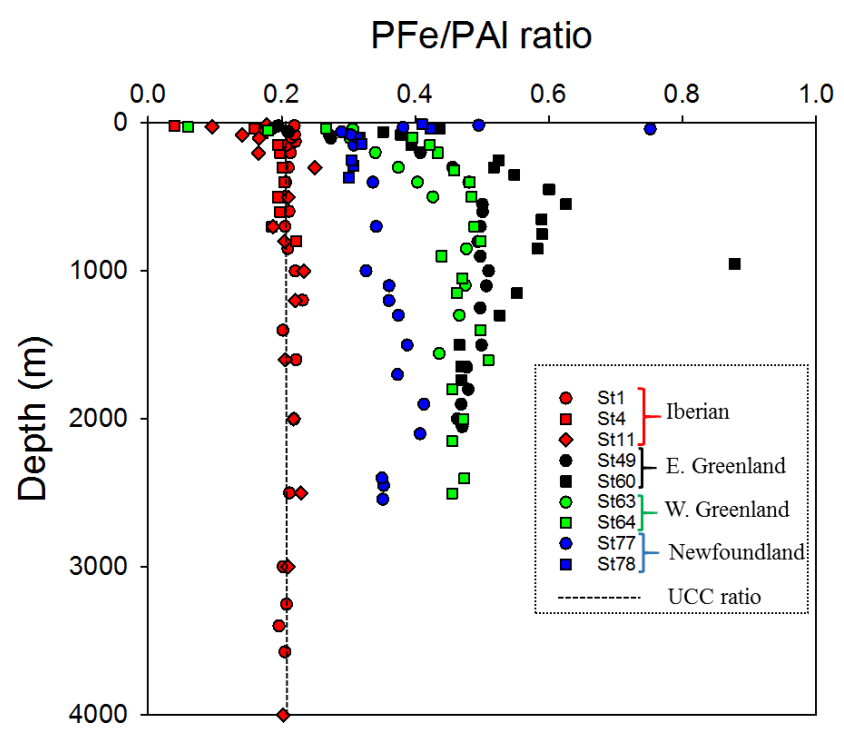

Figure 9. Scatter of the $\mathrm{PFe} / \mathrm{PAl}$ ratio at the Iberian (red dots), East Greenland (black dots), West Greenland (green dots), and Newfoundland margins (blue dots). Dashed line indicates the UCC $\mathrm{PFe} / \mathrm{PAl}$ ratio (Taylor and McLennan, 1995).

Moreover, in the Irminger and Labrador basins, $\mathrm{PFe} / \mathrm{PAl}$ molar ratios within BNLs were higher than the ones measured within the WEB at stations 26 and 29. In the Irminger Basin, $\mathrm{PFe} / \mathrm{PAl}$ reached $0.4 \mathrm{~mol} \mathrm{~mol}^{-1}$ (Fig. 10b), which could reveal a mixture of lithogenic and biogenic matter that had been previously exported. This feature was also observed in the Labrador Basin, with the PFe/PAl ratio ranging between 0.34 and $0.44 \mathrm{~mol} \mathrm{~mol}^{-1}$. In contrast, BNLs sampled in the WEB clearly have a lithogenic imprint, with PFe/PAl molar ratios close to the crustal one. Resuspended sediments with a non-crustal contribution seem to have higher $\mathrm{PFe}$ contents than sediments with lithogenic characteristics. Nevertheless, interestingly all BNLs present during GEOVIDE were spreading identically, with impacts observable up to $200 \mathrm{~m}$ above the oceanic seafloor (Fig. 10), as reflected in beam transmissometry values, and PFe concentrations, which returned to background levels at $200 \mathrm{~m}$ above the seafloor. The presence of these BNLs has also been reported by Le Roy et al. (2018) using radium-226 activity. Important differences of $\mathrm{PFe}$ intensities could also be due to different hydrographic components and topographic characteristics. BNLs occur due to strong hydrographic stresses (i.e. boundary currents, benthic storms, and deep eddies) interacting with the ocean floor (Eittreim et al., 1976; Biscaye and Eittreim, 1977; Gardner et al., 2017, 2018). They are, by definition, highly variable geographically and temporally, but we have no physical data which would allow us to investigate this hypothesis further. 
(a)

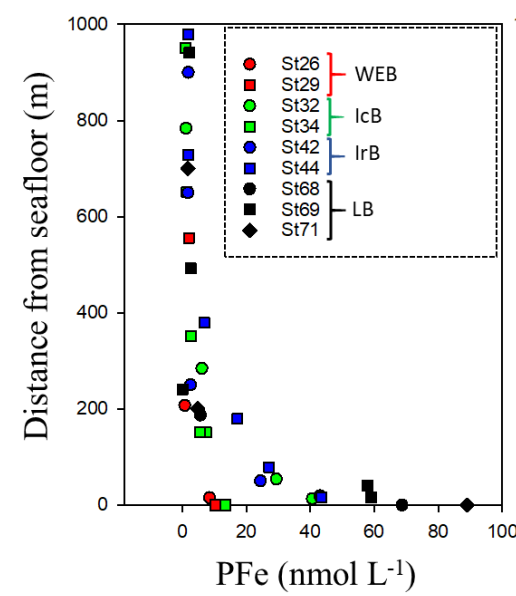

(b)

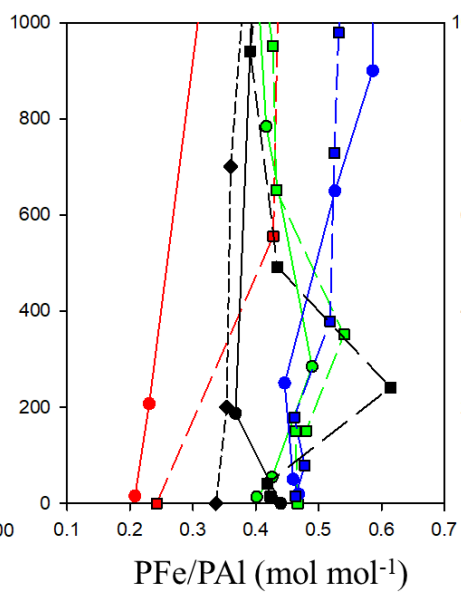

(c)

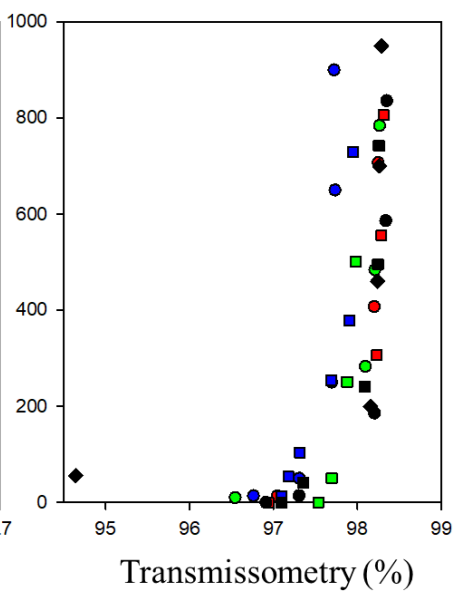

Figure 10. Benthic nepheloid layers (BNLs) encountered along the GA01 section and observed through (a) PFe total, (b) PFe/PAl ratio, and (c) beam transmissometry $(\%)$ as a function of depth above the seafloor $(\mathrm{m})$ at selected stations where a decrease in transmissometry was recorded in the West European (red dots), Iceland (green dots), Irminger (blue dots), and Labrador basins. Noted that the UCC PFe/PAl ratio reported from Taylor and McLennan (1995) is $0.21 \mathrm{~mol} \mathrm{~mol}^{-1}$.

\subsubsection{Reykjanes Ridge inputs}

Above the Reykjanes Ridge (station 38), high PFe concentrations were determined, reaching $16 \mathrm{nmol} \mathrm{L}^{-1}$ just above the seafloor, while increased $\mathrm{DFe}$ concentrations were reported to the east of the ridge (Tonnard et al., 2018, this issue). The exact sources of iron-rich particles cannot be well constrained, as they could come from active hydrothermal vents or resuspension of particulate matter from new crustal matter produced at the ridge. According to the oceanic circulation (Garcia-Ibanez et al., 2017; Zunino et al., 2017), hydrothermal particles could have been seen in the ISOW within the Icelandic Basin. Nevertheless, at the vicinity of the ridge, scanning electron microscope (SEM) analyses of our samples did reveal several biological debris and clays but not the presence of iron (oxy-)hydroxide particles (Fig. S1 in the Supplement), which are known to be produced close to hydrothermal vents (Elderfield and Schultz, 1996). Their absence could thus indicate an absence of vents. However, data from other proxies, such as helium-3, would be necessary to confirm the presence or absence of a hydrothermal source close to station 38 .

\subsubsection{Atmospheric inputs}

Atmospheric deposition is an important source of trace elements in the surface of the open ocean (e.g. Jickells et al., 2005). Atmospheric inputs, both wet and dry, were reported to be low during the GEOVIDE cruise (Shelley et al., 2018; Menzel Barraqueta et al., 2018b, this issue). In fact, oceanic particle measurements in surface waters along the section did not reveal high $\mathrm{PFe}$ or PAl concentrations. One pattern is interesting to note: the surface waters of the Iberian Abyssal
Plain and Western European Basin, between stations 11 and 23 , presented a characteristic feature with really low $\mathrm{PFe} / \mathrm{PAl}$ elemental ratios, of 0.11 , smaller than the UCC ratio of 0.21 (Fig. 6a). Such low ratios have been reported in the same region by Barrett et al. (2012). One possible explanation is given by Buck et al. (2010), who described Fe-depleted aerosols in this area of the North Atlantic with a PFe/PAl ratio below the UCC ratio. However, Shelley et al. (2017) found a higher $\mathrm{PFe} / \mathrm{PAl}$ ratio of around 0.25 is this area (their samples geoa5-6). This result highlights some of the difficulties in linking atmospheric inputs to water column data (Baker et al., 2016) and implies a probable fractionation after aerosol deposition. In addition, there is high spatial and temporal variability of atmospheric deposition (Mahowald et al., 2005) and a certain degree of uncertainty about the dissolution processes of atmospherically transported particles (Bonnet and Guieu, 2004).

\section{Conclusions}

The investigation of the PFe composition of suspended particulate matter along the GEOVIDE section in the North Atlantic reflects the pervasive influence of crustal particles, augmented by sedimentary inputs at margins, and within benthic nepheloid layers at depths. In consequence, variance of particulate iron along the section is mainly explained by lithogenic factors.

Resuspension of sedimentary particles from continental shelves is responsible for high particulate iron concentrations within the surrounding water column and could be observed at long distances from the shelf, in the case of the Iberian margin. Our results also demonstrate the impact of Arctic meteoric water on the Greenland Shelf, while in surface wa- 
ters, the enhancement of productivity by new bioavailable iron leads to a transfer of dissolved iron to the particulate phase. Benthic nepheloid layers provide important concentrations of particles to the water column; they were observed in most of the oceanic basin encountered along the GEOVIDE section.

Overall, PFe distributions in the North Atlantic are strongly influenced by sources at its boundaries (i.e. continental margins and seafloor). When combined with other datasets from the GEOTRACES programme in a modelling study, for example, use of this data will facilitate a greater understanding of particulate iron cycling in the North Atlantic.

Data availability. All GEOVIDE data are deposited in the LEFE CYBER (2019) database (http://www.obs-vlfr.fr/proof/php/ geovide/x_datalist_1.php?xxop=geovide\&xxcamp=geovide). They will also be submitted to the next GEOTRACES Intermediate Data Product.

Supplement. The supplement related to this article is available online at: https://doi.org/10.5194/bg-16-1563-2019-supplement.

Author contributions. AG and HP wrote this paper with the advice and remarks of the other co-authors. AG accomplished all the analysis of particulate trace elements with the help of HP. HP, MC, NL, JLMB, and RS accomplished the sampling during the GEOVIDE cruise. The project was conceived and funded with the help of HP, PL, and GS.

Competing interests. The authors declare that they have no conflict of interest.

Special issue statement. This article is part of the special issue "GEOVIDE, an international GEOTRACES study along the OVIDE section in the North Atlantic and in the Labrador Sea (GA01)". It is not associated with a conference.

Acknowledgements. We are greatly indebted to the captain and crew of the N/O Pourquoi Pas? for their help during the GEOVIDE mission and clean rosette deployment. We would like to give special thanks to Fabien Pérault and Emmanuel de Saint Léger for their technical expertise, to Catherine Schmechtig for the GEOVIDE database management, and to Greg Cutter for his guidance in setting up the new French clean sampling system. We would like to thank both reviewers for constructive comments that greatly improved this paper. We especially would like to highlight the contribution of Christian Schlosser as a reviewer.

We also would like to thank Reiner Schlitzer for the Ocean Data View software (ODV).

This work was supported by the French National Research Agency (ANR-13-BS06-0014, ANR-12-PDOC-0025-01), the French National Centre for Scientific Research (CNRS-LEFECYBER), the LabexMER (ANR-10-LABX-19), and Ifremer. It was supported for the logistics by DT-INSU and GENAVIR.

Review statement. This paper was edited by Catherine Jeandel and reviewed by two anonymous referees.

\section{References}

Abadie, C., Lacan, F., Radic, A., Pradoux, C., and Poitrasson, F.: Iron isotopes reveal distinct dissolved iron sources and pathways in the intermediate versus deep Southern Ocean, P. Natl. Acad. Sci. USA, 114, 1-6, https://doi.org/10.1073/pnas.1603107114, 2017.

Aguilar-Islas, A. M., Rember, R., Nishino, S., Kikuchi, T., and Itoh, M.: Partitioning and lateral transport of iron to the Canada Basin, Polar Sci., 7, 82-99, https://doi.org/10.1016/j.polar.2012.11.001, 2013.

Baker, A. R., Adams, C., Bell, T. G., Jickells, T. D., and Ganzeveld, L.: Estimation of atmospheric nutrient inputs to the Atlantic Ocean from $50^{\circ} \mathrm{N}$ to $50^{\circ} \mathrm{S}$ based on large-scale field sampling: Iron and other dust-associated elements, Global Biogeochem. Cy., 27, 755-767, https://doi.org/10.1002/gbc.20062, 2013.

Baker, A. R., Landing, W. M., Bucciarelli, E., Cheize, M., Fietz, S., Hayes, C. T., Kadko, D., Morton, P. L., Rogan, N., Sarthou, G., Shelley, R. U., Shi, Z., Shiller, A., and van Hulten, M. M. P.: Trace element and isotope deposition across the air-sea interface: progress and research needs, Philos. T. Roy. Soc. A, 374, 20160190, https://doi.org/10.1098/rsta.2016.0190, 2016.

Barrett, P. M., Resing, J. A., Buck, N. J., Buck, C. S., Landing, W. M., and Measures, C. I.: The trace element composition of suspended particulate matter in the upper $1000 \mathrm{~m}$ of the eastern North Atlantic Ocean: A16N, Mar. Chem., 142-144, 41-53, https://doi.org/10.1016/j.marchem.2012.07.006, 2012.

Benetti, M., Reverdin, G., Lique, C., Yashayaev, I., Holliday, N. P., Tynan, E., Torres-Valdes, S., Lherminier, P., Tréguer, P., and Sarthou, G.: Composition of freshwater in the spring of 2014 on the southern Labrador shelf and slope, J. Geophys. Res.-Oceans, 122, 1102-1121, 10.1002/2016jc012244, 2017.

Berger, C. J. M., Lippiatt, S. M., Lawrence, M. G., and Bruland, K. W.: Application of a chemical leach technique for estimating labile particulate aluminum, iron, and manganese in the Columbia River plume and coastal waters off Oregon and Washington, J. Geophys. Res., 113, C00B01, https://doi.org/10.1029/2007JC004703, 2008.

Bergquist, B. A., Wu, J., and Boyle, E. A.: Variability in oceanic dissolved iron is dominated by the colloidal fraction, Geochim. Cosmochim. Ac., 71, 2960-2974, https://doi.org/10.1016/j.gca.2007.03.013, 2007.

Bhatia, M. P., Kujawinski, E. B., Das, S. B., Breier, C. F., Henderson, P. B., and Charette, M. A.: Greenland meltwater as a significant and potentially bioavailable source of iron to the ocean, Nat. Geosci., 6, 274-278, https://doi.org/10.1038/ngeo1746, 2013.

Biscaye, P. E. and Eittreim, S. L.: Suspended Particulate Loads and Transports in the Nepheloid Layer of the Abyssal Atlantic Ocean, Dev. Sedimentol., 23, 155-172, https://doi.org/10.1016/S00704571(08)70556-9, 1977. 
Bishop, J. K. B. and Biscaye, P. E.: Chemical characterization of individual particles from the nepheloid layer in the Atlantic Ocean, Earth Planet. Sc. Lett., 58, 265-275, https://doi.org/10.1016/0012-821X(82)90199-6, 1982.

Bishop, J. K. B. and Fleisher, M. Q.: Particulate manganese dynamics in Gulf Stream warm-core rings and surrounding waters of the N.W. Atlantic, Geochim. Cosmochim. Ac., 51, 2807-2825, https://doi.org/10.1016/0016-7037(87)90160-8, 1987.

Bonnet, S. and Guieu, C.: Dissolution of atmospheric iron in seawater, Geophys. Res. Lett., 31, L03303, https://doi.org/10.1029/2003GL018423, 2004.

Boyle, E. A., Bergquist, B. A., Kayser, R. A., and Mahowald, N.: Iron, manganese, and lead at Hawaii Ocean Time-series station ALOHA: Temporal variability and an intermediate water hydrothermal plume, Geochim. Cosmochim. Ac., 69, 933-952, https://doi.org/10.1016/j.gca.2004.07.034, 2005.

Buck, C. S., Landing, W. M., Resing, J. A., and Measures, C. I.: The solubility and deposition of aerosol $\mathrm{Fe}$ and other trace elements in the North Atlantic Ocean: Observations from the A16N CLIVAR/CO2repeat hydrography section, Mar. Chem., 120, 57-70, https://doi.org/10.1016/j.marchem.2008.08.003, 2010.

Cheize, M., Planquette, H. F., Fitzsimmons, J. N., Pelleter, E., Sherrell, R. M., Lambert, C., Bucciarelli, E., Sarthou, G., Le Goff, M., Liorzou, C., Chéron, S., Viollier, E., and Gayet, N.: Contribution of resuspended sedimentary particles to dissolved iron and manganese in the ocean: An experimental study, Chem. Geol., 511, 389-415, https://doi.org/10.1016/j.chemgeo.2018.10.003, 2018.

Collier, R. and Edmond, J.: The trace element geochemistry of marine biogenic particulate matter, Prog. Oceanogr., 13, 113-199, https://doi.org/10.1016/0079-6611(84)90008-9, 1984.

Cullen, J. T., Chong, M., and Ianson, D.: British columbian continental shelf as a source of dissolved iron to the subarctic northeast Pacific Ocean, Global Biogeochem. Cy., 23, 1-12, https://doi.org/10.1029/2008GB003326, 2009.

Cutter, G. A. and Bruland, K. W.: Rapid and noncontaminating sampling system for trace elements in global ocean surveys, Limnol. Oceanogr.-Meth., 10, 425-436, https://doi.org/10.4319/lom.2012.10.425, 2012.

Dammshäuser, A., Wagener, T., Garbe-Schönberg, D., and Croot, P.: Particulate and dissolved aluminum and titanium in the upper water column of the Atlantic Ocean, Deep-Sea Res. Pt. I, 73, 127-139, https://doi.org/10.1016/j.dsr.2012.12.002, 2013.

Dehairs, F., Jacquet, S., Savoye, N., Van Mooy, B. A. S., Buesseler, K. O., Bishop, J. K. B., Lamborg, C. H., Elskens, M., Baeyens, W., Boyd, P. W., Casciotti, K. L., and Monnin, C.: Barium in twilight zone suspended matter as a potential proxy for particulate organic carbon remineralization: Results for the North Pacific, Deep-Sea Res. Pt. II, 55, 1673-1683, https://doi.org/10.1016/j.dsr2.2008.04.020, 2008.

Dutay, J. C., Tagliabue, A., Kriest, I., and van Hulten, M. M. P.: Modelling the role of marine particle on large scale ${ }^{231} \mathrm{~Pa},{ }^{230} \mathrm{Th}$, Iron and Aluminium distributions, Prog. Oceanogr., 133, 66-72, https://doi.org/10.1016/j.pocean.2015.01.010, 2015.

Eittreim, S., Thorndike, E. M., and Sullivan, L.: Turbidity distribution in the Atlantic Ocean, Deep-Sea Res., 23, 1115-1127, https://doi.org/10.1016/0011-7471(76)90888-3, 1976.

Elderfield, H. and Schultz, A.: Mid-Ocean Ridge Hydrothermal Fluxes and the Chemical Composition of the Ocean, Annu. Rev. Earth Pl. Sc., 24, 191-224, https://doi.org/10.1146/annurev.earth.24.1.191, 1996.

Ellwood, M. J., Nodder, S. D., King, A. L., Hutchins, D. A., Wilhelm, S. W., and Boyd, P. W.: Pelagic iron cycling during the subtropical spring bloom, east of New Zealand, Mar. Chem., 160, 18-33, https://doi.org/10.1016/j.marchem.2014.01.004, 2014.

Elrod, V. A., Berelson, W. M., Coale, K. H., and Johnson, K. S.: The flux of iron from continental shelf sediments: A missing source for global budgets, Geophys. Res. Lett., 31, 2-5, https://doi.org/10.1029/2004GL020216, 2004.

Fitzwater, S. E., Johnson, K. S., Gordon, R. M., Coale, K. H., and Smith, W. O.: Trace metal concentrations in athe Ross Sea and their relationship with nutrients and phytoplankton growth, Deep-Sea Res. Pt. II, 47, 3159-3179, https://doi.org/10.1016/S0967-0645(00)00063-1, 2000.

Fragoso, G. M., Poulton, A. J., Yashayaev, I. M., Head, E. J. H., Stinchcombe, M. C., and Purdie, D. A.: Biogeographical patterns and environmental controls of phytoplankton communities from contrasting hydrographical zones of the Labrador Sea, Prog. Oceanogr., 141, 212-226, https://doi.org/10.1016/j.pocean.2015.12.007, 2016.

Frew, R. D., Hutchins, D. A., Nodder, S., Sanudo-Wilhelmy, S., Tovar-Sanchez, A., Leblanc, K., Hare, C. E., and Boyd, P. W.: Particulate iron dynamics during FeCycle in subantarctic waters southeast of New Zealand, Global Biogeochem. Cy., 20, 1-15, https://doi.org/10.1029/2005GB002558, 2006.

García-Ibáñez, M. I., Pardo, P. C., Carracedo, L. I., Mercier, H., Lherminier, P., Ríos, A. F., and Pérez, F. F.: Structure, transports and transformations of the water masses in the Atlantic Subpolar Gyre, Prog. Oceanogr., 135, 18-36, https://doi.org/10.1016/j.pocean.2015.03.009, 2015.

Gardner, W. D., Tucholke, B. E., Richardson, M. J., and Biscaye, P. E.: Benthic storms, nepheloid layers, and linkage with upper ocean dynamics in the western North Atlantic, Mar. Geol., 385 , 304-327, https://doi.org/10.1016/j.margeo.2016.12.012, 2017.

Gardner, W. D., Richardson, M. J., and Mishonov, A. V.: Global assessment of benthic nepheloid layers and linkage with upper ocean dynamics, Earth Planet. Sc. Lett., 482, 126-134, https://doi.org/10.1016/j.eps1.2017.11.008, 2018.

Gerringa, L. J. A., Rijkenberg, M. J. A., Schoemann, V., Laan, P., and de Baar, H. J. W.: Organic complexation of iron in the West Atlantic Ocean, Mar. Chem., 177, 434-446, https://doi.org/10.1016/j.marchem.2015.04.007, 2015.

Hawkings, J. R., Wadham, J. L., Tranter, M., Raiswell, R., Benning, L. G., Statham, P. J., Tedstone, A., Nienow, P., Lee, K., and Telling, J.: Ice sheets as a significant source of highly reactive nanoparticulate iron to the oceans, Nat. Commun., 5, 1-8, https://doi.org/10.1038/ncomms4929, 2014.

Hwang, J., Druffel, E. R. M., and Eglinton, T. I.: Widespread influence of resuspended sediments on oceanic particulate organic carbon: Insights from radiocarbon and aluminum contents in sinking particles, Global Biogeochem. Cy., 24, 1-10, https://doi.org/10.1029/2010GB003802, 2010.

Jeandel, C. and Oelkers, E. H.: The influence of terrigenous particulate material dissolution on ocean chemistry and global element cycles, Chem. Geol., 395, 50-66, https://doi.org/10.1016/j.chemgeo.2014.12.001, 2015.

Jeandel, C., Peucker-Ehrenbrink, B., Jones, M. T., Pearce, C. R., Oelkers, E. H., Godderis, Y., Lacan, F., Aumont, O., and Ar- 
souze, T.: Ocean margins: The missing term in oceanic element budgets?, Eos, Transactions American Geophysical Union, 92, 217-224, https://doi.org/10.1029/2011EO260001, 2011.

Jickells, T. D., An, Z. S., Andersen, K. K., Baker, A. R., Bergametti, C., Brooks, N., Cao, J. J., Boyd, P. W., Duce, R. A., Hunter, K. A., Kawahata, H., Kubilay, N., LaRoche, J., Liss, P. S., Mahowald, N., Prospero, J. M., Ridgwell, A. J., Tegen, I., and Torres, R.: Global iron connections between desert dust, ocean biogeochemistry, and climate, Science, 308, 67-71, https://doi.org/10.1126/science.1105959, 2005.

Jouanneau, J. M., Garcia, C., Oliveira, A., Rodrigues, A., Dias, J. A., and Weber, O.: Dispersal and deposition of suspended sediment on the shelf off the Tagus and Sado estuaries, S.W. Portugal, Prog. Oceanogr., 42, 233-257, https://doi.org/10.1016/S00796611(98)00036-6, 1998.

Labatut, M., Lacan, F., Pradoux, C., Chmeleff, J., Radic, A., Murray, J. W., Poitrasson, F., Johansen, A. M., Thil, F., Lacan, F., Pradoux, C., Chmeleff, J., Radic, A., Murray, J. W., Poitrasson, F., Johansen, A. M., and Thil, F.: Iron sources and dissolvedparticulate interactions in the seawater of the Western Equatorial Pacific, iron isotope perspectives, Global Biogeochem. Cy., 28, 1044-1065, https://doi.org/10.1002/2014GB004928, 2014.

Lam, P. J. and Bishop, J. K. B.: The continental margin is a key source of iron to the HNLC North Pacific Ocean, Geophys. Res. Lett., 35, 1-5, https://doi.org/10.1029/2008GL033294, 2008.

Lam, P. J., Ohnemus, D. C., and Marcus, M. A.: The speciation of marine particulate iron adjacent to active and passive continental margins, Geochim. Cosmochim. Ac., 80, 108-124, https://doi.org/10.1016/j.gca.2011.11.044, 2012.

Lam, P. J., Ohnemus, D. C., and Auro, M. E.: Size-fractionated major particle composition and concentrations from the US GEOTRACES North Atlantic Zonal Transect, Deep-Sea Res. Pt. II, 116, 303-320, https://doi.org/10.1016/j.dsr2.2014.11.020, 2015.

Lam, P. J., Lee, J. M., Heller, M. I., Mehic, S., Xiang, Y., and Bates, N. R.: Size-fractionated distributions of suspended particle concentration and major phase composition from the U.S. GEOTRACES Eastern Pacific Zonal Transect (GP16), Mar. Chem., 201, 90-107, https://doi.org/10.1016/j.marchem.2017.08.013, 2017.

Lannuzel, D., Bowie, A. R., van der Merwe, P. C., Townsend, A. T., and Schoemann, V.: Distribution of dissolved and particulate metals in Antarctic sea ice, Mar. Chem., 124, 134-146, https://doi.org/10.1016/j.marchem.2011.01.004, 2011.

Lannuzel, D., Van der Merwe, P. C., Townsend, A. T., and Bowie, A. R.: Size fractionation of iron, manganese and aluminium in Antarctic fast ice reveals a lithogenic origin and low iron solubility, Mar. Chem., 161, 47-56, https://doi.org/10.1016/j.marchem.2014.02.006, 2014.

Lee, J. M., Heller, M. I., and Lam, P. J.: Size distribution of particulate trace elements in the U.S. GEOTRACES Eastern Pacific Zonal Transect (GP16), Mar. Chem., 201, 108-123, https://doi.org/10.1016/j.marchem.2017.09.006, 2017.

LEFE CYBER: GEOVIDE data, available at: http: //www.obs-vlfr.fr/proof/php/geovide/x_datalist_1.php?xxop= geovide\&xxcamp=geovide, last access: 10 April 2019.

Lemaitre, N., Planquette, H., Planchon, F., Sarthou, G., Jacquet, S., García-Ibáñez, M. I., Gourain, A., Cheize, M., Monin, L., André, L., Laha, P., Terryn, H., and Dehairs, F.: Particulate barium tracing of significant mesopelagic carbon reminerali- sation in the North Atlantic, Biogeosciences, 15, 2289-2307, https://doi.org/10.5194/bg-15-2289-2018, 2018.

Le Roy, E., Sanial, V., Charette, M. A., van Beek, P., Lacan, F., Jacquet, S. H. M., Henderson, P. B., Souhaut, M., García-Ibáñez, M. I., Jeandel, C., Pérez, F. F., and Sarthou, G.: The ${ }^{226}$ Ra-Ba relationship in the North Atlantic during GEOTRACES-GA01, Biogeosciences, 15, 3027-3048, https://doi.org/10.5194/bg-153027-2018, 2018.

Mahowald, N. M., Baker, A. R., Bergametti, G., Brooks, N., Duce, R. A., Jickells, T. D., Kubilay, N., Prospero, J. M., and Tegen, I.: Atmospheric global dust cycle and iron inputs to the ocean, Global Biogeochem. Cy., 19, 5, https://doi.org/10.1029/2004GB002402, 2005.

Marsay, C. M., Lam, P. J., Heller, M. I., Lee, J. M., and John, S. G.: Distribution and isotopic signature of ligand-leachable particulate iron along the GEOTRACES GP16 East Pacific Zonal Transect, Mar. Chem., 201, 1-14, https://doi.org/10.1016/j.marchem.2017.07.003, 2017.

Martin, J. H., Fitzwater, S. E., Michael Gordon, R., Hunter, C. N., and Tanner, S. J.: Iron, primary production and carbon-nitrogen flux studies during the JGOFS North Atlantic bloom experiment, Deep-Sea Res. Pt. II, 40, 115-134, https://doi.org/10.1016/09670645(93)90009-C, 1993.

McCave, I. N. and Hall, I. R.: Turbidity of waters over the Northwest Iberian continental margin, Prog. Oceanogr., 52, 299-313, https://doi.org/10.1016/S0079-6611(02)00012-5, 2002.

Menzel Barraqueta, J.-L., Schlosser, C., Planquette, H., Gourain, A., Cheize, M., Boutorh, J., Shelley, R., Contreira Pereira, L., Gledhill, M., Hopwood, M. J., Lacan, F., Lherminier, P., Sarthou, G., and Achterberg, E. P.: Aluminium in the North Atlantic Ocean and the Labrador Sea (GEOTRACES GA01 section): roles of continental inputs and biogenic particle removal, Biogeosciences, 15, 5271-5286, https://doi.org/10.5194/bg-155271-2018, 2018a.

Menzel Barraqueta, J.-L., Klar, J. K., Gledhill, M., Schlosser, C., Shelley, R., Planquette, H., Wenzel, B., Sarthou, G., and Achterberg, E. P.: Atmospheric aerosol deposition fluxes over the Atlantic Ocean: A GEOTRACES case study, Biogeosciences Discuss., https://doi.org/10.5194/bg-2018-209, in review, 2018b.

Milne, A., Schlosser, C., Wake, B. D., Achterberg, E. P., Chance, R., Baker, A. R., Forryan, A., and Lohan, M. C.: Particulate phases are key in controlling dissolved iron concentrations in the (sub)tropical North Atlantic, Geophys. Res. Lett., 44, 23772387, https://doi.org/10.1002/2016GL072314, 2017.

Nuester, J., Shema, S., Vermont, A., Fields, D. M., and Twining, B. S.: The regeneration of highly bioavailable iron by meso- and microzooplankton, Limnol. Oceanogr., 59, 13991409, https://doi.org/10.4319/lo.2014.59.4.1399, 2014.

Oelkers, E. H., Jones, M. T., Pearce, C. R., Jeandel, C., Eiriksdottir, E. S., and Gislason, S. R.: Riverine particulate material dissolution in seawater and its implications for the global cycles of the elements, Geosci., 344, 646-651, https://doi.org/10.1016/j.crte.2012.08.005, 2012.

Ohnemus, D. C. and Lam, P. J.: Cycling of lithogenic marine particles in the US GEOTRACES North Atlantic transect, Deep-Sea Res. Pt. II, 116, 283-302, https://doi.org/10.1016/j.dsr2.2014.11.019, 2015.

Peers, G. and Price, N. M.: A role for manganese in superoxide dismutases and growth of iron- 
deficient diatoms, Limnol. Oceanogr., 49, 1774-1783, https://doi.org/10.4319/lo.2004.49.5.1774, 2004.

Planquette, H. and Sherrell, R. M.: Sampling for particulate trace element determination using water sampling bottles: Methodology and comparison to in situ pumps, Limnol. Oceanogr.-Meth., 10, 367-388, https://doi.org/10.4319/lom.2012.10.367, 2012.

Planquette, H., Fones, G. R., Statham, P. J., and Morris, P. J.: Origin of iron and aluminium in large particles $(>53 \mu \mathrm{m})$ in the Crozet region, Southern Ocean, Mar. Chem., 115, 31-42, https://doi.org/10.1016/j.marchem.2009.06.002, 2009.

Planquette, H., Sanders, R. R., Statham, P. J., Morris, P. J., and Fones, G. R.: Fluxes of particulate iron from the upper ocean around the Crozet Islands: A naturally iron-fertilized environment in the Southern Ocean, Global Biogeochem. Cy., 25, 10, https://doi.org/10.1029/2010GB003789, 2011.

Planquette, H., Sherrell, R. M., Stammerjohn, S., and Field, M. P.: Particulate iron delivery to the water column of the Amundsen Sea, Antarctica, Mar. Chem., 153, 15-30, https://doi.org/10.1016/j.marchem.2013.04.006, 2013.

Radic, A., Lacan, F., and Murray, J. W.: Iron isotopes in the seawater of the equatorial Pacific Ocean: New constraints for the oceanic iron cycle, Earth Planet. Sc. Lett., 306, 1-10, https://doi.org/10.1016/j.eps1.2011.03.015, 2011.

Raiswell, R., Benning, L. G., Tranter, M., and Tulaczyk, S.: Bioavailable iron in the Southern Ocean: The significance of the iceberg conveyor belt, Geochem. T., 9, 7, https://doi.org/10.1186/1467-4866-9-7, 2008.

Rijkenberg, M. J. A., Middag, R., Laan, P., Gerringa, L. J. A., Van Aken, H. M., Schoemann, V., De Jong, J. T. M., and De Baar, H. J. W.: The distribution of dissolved iron in the West Atlantic Ocean, PLoS One, 9, 1-14, https://doi.org/10.1371/journal.pone.0101323, 2014.

Sanders, R., Henson, S. A., Koski, M., De La Rocha, C. L., Painter, S. C., Poulton, A. J., Riley, J., Salihoglu, B., Visser, A., Yool, A., Bellerby, R., and Martin, A. P.: The Biological Carbon Pump in the North Atlantic, Prog. Oceanogr., 129, 200-218, https://doi.org/10.1016/j.pocean.2014.05.005, 2014.

Sarthou, G., Lherminier, P., Achterberg, E. P., Alonso-Pérez, F., Bucciarelli, E., Boutorh, J., Bouvier, V., Boyle, E. A., Branellec, P., Carracedo, L. I., Casacuberta, N., Castrillejo, M., Cheize, M., Contreira Pereira, L., Cossa, D., Daniault, N., De Saint-Léger, E., Dehairs, F., Deng, F., Desprez de Gésincourt, F., Devesa, J., Foliot, L., Fonseca-Batista, D., Gallinari, M., García-Ibáñez, M. I., Gourain, A., Grossteffan, E., Hamon, M., Heimbúrger, L. E., Henderson, G. M., Jeandel, C., Kermabon, C., Lacan, F., Le Bot, P., Le Goff, M., Le Roy, E., Lefèbvre, A., Leizour, S., Lemaitre, N., Masqué, P., Ménage, O., Menzel Barraqueta, J.-L., Mercier, H., Perault, F., Pérez, F. F., Planquette, H. F., Planchon, F., Roukaerts, A., Sanial, V., Sauzède, R., Schmechtig, C., Shelley, R. U., Stewart, G., Sutton, J. N., Tang, Y., Tisnérat-Laborde, N., Tonnard, M., Tréguer, P., van Beek, P., Zurbrick, C. M., and Zunino, P.: Introduction to the French GEOTRACES North Atlantic Transect (GA01): GEOVIDE cruise, Biogeosciences, 15, 7097-7109, https://doi.org/10.5194/bg-15-7097-2018, 2018.

Sarthou, G., Vincent, D., Christaki, U., Obernosterer, I., Timmermans, K. R., and Brussaard, C. P. D.: The fate of biogenic iron during a phytoplankton bloom induced by natural fertilisation: Impact of copepod grazing, Deep-Sea Res. Pt. II, 55, 734-751, https://doi.org/10.1016/j.dsr2.2007.12.033, 2008.
Schlosser, C., Schmidt, K., Aquilina, A., Homoky, W. B., Castrillejo, M., Mills, R. A., Patey, M. D., Fielding, S., Atkinson, A., and Achterberg, E. P.: Mechanisms of dissolved and labile particulate iron supply to shelf waters and phytoplankton blooms off South Georgia, Southern Ocean, Biogeosciences, 15, 49734993, https://doi.org/10.5194/bg-15-4973-2018, 2018.

Shelley, R. U., Landing, W. M., Ussher, S. J., Planquette, H., and Sarthou, G.: Regional trends in the fractional solubility of Fe and other metals from North Atlantic aerosols (GEOTRACES cruises GA01 and GA03) following a two-stage leach, Biogeosciences, 15, 2271-2288, https://doi.org/10.5194/bg-15-2271-2018, 2018.

Sherrell, R. M., Field, P. M., and Gao, Y.: Temporal variability of suspended mass and composition in the Northeast Pacific water column: Relationships to sinking flux and lateral advection, Deep-Sea Res. Pt. II, 45, 733-761, https://doi.org/10.1016/S0967-0645(97)00100-8, 1998.

Spinrad, R. W., Zaneveld, J. R., and Kitchen, J. C.: A Study of the Optical Characteristics of the Suspended Particles Benthic N epheloid Layer of the Scotian Rise, J. Geophys. Res., 88, 76417645, https://doi.org/10.1029/JC088iC12p07641, 1983.

Statham, P. J., Skidmore, M., and Tranter, M.: Inputs of glacially derived dissolved and colloidal iron to the coastal ocean and implications for primary productivity, Global Biogeochem. Cy., 22, 1-11, https://doi.org/10.1029/2007GB003106, 2008.

Straneo, F., Pickart, R. S., and Lavender, K.: Spreading of Labrador sea water: An advective-diffusive study based on Lagrangian data, Deep-Sea Res. Pt. I, 50, 701-719, https://doi.org/10.1016/S0967-0637(03)00057-8, 2003.

Sunda, W. G. and Huntsman, S. A.: Effect of Competitive Interactions Between Manganese and Copper on Cellular Manganese and Growth in Estuarine and Oceanic Species of the Diatom Thalassiosira, Limnol. Oceanogr., 28, 924-934, https://doi.org/10.4319/lo.1983.28.5.0924, 1983.

Tagliabue, A., Bopp, L., Dutay, J. C., Bowie, A. R., Chever, F., JeanBaptiste, P., Bucciarelli, E., Lannuzel, D., Remenyi, T., Sarthou, G., Aumont, O., Gehlen, M., and Jeandel, C.: Hydrothermal contribution to the oceanic dissolved iron inventory, Nat. Geosci., 3, 252-256, https://doi.org/10.1038/ngeo818, 2010.

Tagliabue, A., Bowie, A. R., Boyd, P. W., Buck, K. N., Johnson, K. S., and Saito, M. A.: The integral role of iron in ocean biogeochemistry, Nature, 543, 51-59, https://doi.org/10.1038/nature21058, 2017.

Taylor, S. and McLennan, S.: The geochemical evolution of the continental crust, Rev. Geophys., 33, 241-265, https://doi.org/10.1029/95RG00262, 1995.

Tonnard, M., Planquette, H., Bowie, A. R., van der Merwe, P., Gallinari, M., Desprez de Gésincourt, F., Germain, Y., Gourain, A., Benetti, M., Reverdin, G., Tréguer, P., Boutorh, J., Cheize, M., Menzel Barraqueta, J.-L., Pereira-Contreira, L., Shelley, R., Lherminier, P., and Sarthou, G.: Dissolved iron in the North Atlantic Ocean and Labrador Sea along the GEOVIDE section (GEOTRACES section GA01), Biogeosciences Discuss., https://doi.org/10.5194/bg-2018-147, in review, 2018.

Trefry, J. H., Trocine, R. P., Klinkhammer, G. P., and Rona, P. A.: Iron and copper enrichment of suspended particles in dispersed hydrothermal plumes along the mid-Atlantic Ridge, Geophys. Res. Lett., 12, 506-509, https://doi.org/10.1029/GL012i008p00506, 1985. 
Ussher, S. J., Achterberg, E. P., and Worsfold, P. J.: Marine biogeochemistry of iron, Environ. Chem., 1, 67-80, https://doi.org/10.1071/EN04053, 2004.

Ussher, S. J., Worsfold, P. J., Achterberg, E. P., Laës, A., Blain, S., Laan, P., de Baar, H. J. W.: Distribution and redox speciation of dissolved iron on the European continental margin, Limnol. Oceanogr., 52, 2530-2539, https://doi.org/10.4319/lo.2007.52.6.2530, 2007.

van der Merwe, P., Lannuzel, D., Bowie, A. R., Mancuso Nichols, C. A., and Meiners, K. M.: Iron fractionation in pack and fast ice in East Antarctica: Temporal decoupling between the release of dissolved and particulate iron during spring melt, Deep-Sea Res. Pt. II, 58, 1222-1236, https://doi.org/10.1016/j.dsr2.2010.10.036, 2011a.

van Der Merwe, P., Lannuzel, D., Bowie, A. R., and Meiners, K. M.: High temporal resolution observations of spring fast ice melt and seawater iron enrichment in East Antarctica, J. Geophys. Res.Biogeo., 116, 1-18, https://doi.org/10.1029/2010JG001628, $2011 b$.
Weinstein, S. E. and Moran, S. B.: Distribution of size-fractionated particulate trace metals collected by bottles and in situ pumps in the Gulf of Maine-Scotian Shelf and Labrador Sea, Mar. Chem., 87, 121-135, https://doi.org/10.1016/j.marchem.2004.02.004, 2004.

Yashayaev, I.: Hydrographic changes in the Labrador Sea, 1960-2005, Prog. Oceanogr., 73, 242-276, https://doi.org/10.1016/j.pocean.2007.04.015, 2007.

Yashayaev, I. and Loder, J. W.: Enhanced production of Labrador Sea Water in 2008, Geophys. Res. Lett., 36, 26, https://doi.org/10.1029/2008GL036162, 2009.

Zunino, P., Lherminier, P., Mercier, H., Daniault, N., García-Ibáñez, M. I., and Pérez, F. F.: The GEOVIDE cruise in May-June 2014 reveals an intense Meridional Overturning Circulation over a cold and fresh subpolar North Atlantic, Biogeosciences, 14, 5323-5342, https://doi.org/10.5194/bg-14-5323-2017, 2017. 